\title{
Judicial Review of Arbitral Awards and Parties' Right to Expand It
}

\author{
Sanela Ninković*
}

Table of Contents

A. Introduction 486

B. Recourse against an arbitral award $\quad 487$

I. Place of recourse against an arbitral award 488

II. The purpose and effect of recourse against an arbitral award 489

III. A general trend towards limiting court intervention 489

IV. Limiting recourse against an arbitral award to the setting aside procedure $\quad 490$

1. No review on the merits in a setting aside procedure 490

2. No review on the merits when setting aside on grounds of "public policy" 491

C. Contractual extension of judicial review - do parties have a right thereto? 492

I. Mandatory rules as a limitation on parties' freedom to contract 493

II. Party autonomy and the finality of an award 493

1. Party autonomy 494

2. Finality of an award 494

D. Judicial review and parties' right of expansion under the UNCITRAL Model Law on International Commercial Arbitration

I. Relevant provisions and possible interpretations 496

1. Textual interpretation 497

2. Subjective interpretation 497

II. Judicial decisions in Model Law jurisdictions $\quad 501$

1. Rulings prohibiting expanded judicial review 501

2. Ruling allowing an expanded judicial review $\quad 502$

a) De novo review: falling under the Model Law or not? 503

b) Decision and reasoning $\quad 504$

c) Criticism of the decision $\quad 505$

$\begin{array}{ll}\text { III. Conclusion } & 507\end{array}$

* Sanela Ninković LL.M. is working as a trainee at the European Commission from October 2014. The author finished the Master's Program "European and International Law" at the Europa-Institut, Saarland University, with specialisations in European Economic Law, Foreign Trade and Investment as well as International Dispute Resolution. The author is most grateful to Prof. Dr. Dr. h.c. mult. Helmut Rüßmann for the lively discussions and guidance as thesis supervisor. All views expressed in this article are personal to the author. 
E. Judicial review and parties' right of expansion under the U.S. Federal Arbitration Act 507

I. Vacating arbitral awards under section 10 of the FAA 509

II. Judgments prior to the U.S. Supreme Court's ruling in "Hall Street v. Mattel" 509

III. The U.S. Supreme Court's judgment in "Hall Street v. Mattel" 510

IV. Judgments in the aftermath of "Hall Street" 514

$\begin{array}{ll}\text { V. Conclusion } & 517\end{array}$

F. Possible solutions for parties seeking a review on merits 519

I. Jurisdictions explicitly allowing expanded judicial review 519

II. Jurisdictions providing more extensive grounds for annulment 521

III. Appeal to a tribunal of second-instance $\quad 523$

G. Should parties be allowed to expand judicial review?

H. Conclusion $\quad 526$

\section{A. Introduction}

In the current day and age, international commercial arbitration forms the main means of dispute resolution employed by commercial entities. It is commonly accepted that by agreeing to arbitration, parties agree to submit their disputes to a neutral decision-maker, who will render a final and binding award. Consistent with this traditional perception of arbitration, national legislators have enacted provisions specifying the legal frameworks for enforcing arbitral awards, which ordinarily allow only a narrow standard for challenging an award.

In recent years, however, a particular phenomenon has begun to draw much attention, namely the contractually expanded judicial review. Parties are increasingly including provisions in their arbitration agreements that foresee for a review on merits by national courts - a higher degree of scrutiny than that normally allowed by national arbitration laws. Hence, courts find themselves confronted with the question of the validity of such agreements. National arbitration laws unfortunately fail to provide courts with a clear answer, as they neither expressly address this question nor designate rules from which parties may not derogate by way of their agreement. Thus, courts face the difficult task of interpreting the law. The courts' response to the question has, however, not been unanimous. While some courts grant parties the right of expanded review, others deny it, instead invalidating the agreement in part or in its entirety. Such a scattering of opinions is equally present in the academic community. Consequently, parties seeking a review on the merits of an award by state courts are confronted with a tremendous amount of legal uncertainty as regards the validity of such agreements.

The question of contractually expanded judicial review raises numerous complex issues, for instance whether the provision foreseeing for the review on merits can be severed from the rest of the arbitration agreement if found invalid. However, it is beyond the scope of this paper to provide information on all relevant issues. 
This paper will instead examine the currently accepted standard of judicial review and parties' right to expand it under various national laws, with special reference to recent judicial decisions on the matter.

The paper will address the notion of recourse against an arbitral award and national laws' current tendency to limit it. In addition, a distinction between setting aside procedures and a review on merits will be drawn. The paper will further address mandatory rules restricting parties' contractual freedom and the relationship between party autonomy and finality of awards, key elements in judicial reasoning.

Special emphasis will be placed on available recourse and parties right to expand it under the UNCITRAL Model Law on International Commercial Arbitration, the related Model Law jurisdictions and the United States Federal Arbitration Act. In particular, the legal provision regulating recourse against an award will be analysed and recent judgments on expanded judicial review will be elaborated upon. Notably, this paper will not only present the current situation in arbitration but will also take a rather proactive and critical stance on the matter.

The question whether parties should be free to expand judicial review cannot be answered with absolute certainty, as much will depend upon one's understanding of arbitration and its basic features and principles. For this reason, this paper will deal with possible solutions for parties seeking judicial review of the award.

Finally, the paper will comprise the author's opinion and remarks related to parties' right to contractually expand judicial review.

\section{B. Recourse against an arbitral award}

As previously noted, arbitration has become the principal method of dispute settlement between international commercial parties. It results in an arbitral award being rendered by the arbitral tribunal once proceedings come to a close, and in the majority of cases, parties accept the tribunal's decision and voluntarily comply with the arbitral award. ${ }^{1}$ This can possibly be explained by parties' expectation when they agree to arbitration as the method to resolve their disputes. ${ }^{2}$ Parties choose arbitration as an alternative to court litigation, hoping that any potential dispute is decided in an effective and timely manner by a final arbitral award. As a result, the parties commit themselves to accepting and giving effect to the tribunal's decision. ${ }^{3}$ Nevertheless, there are situations where one or both parties do not accept the arbitral award. If both parties are unsatisfied with the award, they can agree to vary the terms of the award and in that way settle their dispute, using the award as a bargaining tool. ${ }^{4}$ However, usually the winning party will be satisfied with the award. Consequently, the unsatisfied party may refuse to comply with the award and instead try to void it. In such cases, that party may decide to either wait until the successful party initiates

1 See Born, International Commercial Arbitration, Vol. III: International Arbitral Awards, 2nd ed. 2014, pp. 2898, 2900.

2 See ibid., p. 2900.

3 See Lew/Mistelis/Kröll, Comparative International Commercial Arbitration, 2003, p. 4.

4 See Blackaby/Partasides et al., Redfern and Hunter on International Arbitration, 5th ed. 2009, p. 582, paras. 9.210 and 9.211 . 
recognition and enforcement of the award and then resist it by invoking the grounds for denial set out in Article V of the New York Convention, ${ }^{5}$ or to make use of available recourse in state courts against the arbitral award, i.e. to challenge the award. ${ }^{6}$ This paper will from this point onwards elaborate on the second option, namely recourse in state courts against an award.

\section{Place of recourse against an arbitral award}

When a party decides to challenge an award in state courts, it should bring the action in the court at the arbitral seat. ${ }^{7}$ That the seat of arbitration is the appropriate place for challenging awards follows from the fact that the court at the seat has supervisory jurisdiction to ensure that the arbitral process is conducted in a fair way. ${ }^{8}$ Such a position is accepted by the UNCITRAL Model Law on International Commercial Arbitration ${ }^{9}$ and the majority of other national arbitration laws. ${ }^{10}$

The same approach can furthermore be found in the New York Convention, whose Article $\mathrm{V}(1)(\mathrm{e})$ states that an award may be

"set aside or challenged by a competent authority of the country in which, or under the laws of which, that award was made."

Notably though, the Convention also provides for the possibility of a challenge in the country under the law of which that award was made. This possibility reflects parties' freedom to subject arbitration to the procedural law of a state other than the state in which the arbitration is seated. ${ }^{11}$ However, it would be ill-advised to select foreign procedural law, as it is neither helpful nor necessary for the parties. In the event of such a choice, the parties and the tribunal would have to have regard to two procedural laws in the arbitral

5 Convention on Recognition and Enforcement of Foreign Arbitral Awards; adopted on 10 June 1958, entered into force on 7 June 1959 (hereinafter: New York Convention).

6 Other terms used for this action include "review", "annulment" or "vacation". See e.g., section 10 of the U.S. Federal Arbitration Act ("vacation") or Article 34 of the UNCITRAL Model Law on International Commercial Arbitration ("recourse" and "set aside").

7 See Moses, The Principles and Practice of International Commercial Arbitration, 2nd ed. 2012, p. 203. See also Blackaby/Partasides, (fn. 4), p. 590 et seq.; Lew/Mistelis/Kröll, (fn. 3), p. 666 et seq.

8 See Moses, (fn. 7), p. 203.

9 See Article 1(2) in connection with Article 34 of the UNCITRAL Model Law on International Commercial Arbitration (hereinafter: Model Law); UNCITRAL Secretariat, Explanatory Note by the UNCITRAL Secretariat on the 1985 Model Law on International Commercial Arbitration as amended in 2006, para. 48. Accord Gharavi, The International Effectiveness of the Annulment of an Arbitral Award, 2002, p. 12.

10 See e.g., United States (section 10 of the Federal Arbitration Act); Switzerland (Article 191 of the Private International Law Act 1987, hereinafter: PILA); France (Article 1504 of the French Code of Civil Procedure); Germany (section 1062 of the German Code of Civil Procedure, hereinafter: ZPO); China (Article 58 of the Arbitration Law); Netherlands (Article 1064a of the Code of Civil Procedure as adopted by the Parliament on the 27 May 2014. The date of entry into force shall be determined by the Minister of Security and Justice with a royal decree). For exceptions of this rule see Gharavi, (fn. 9), pp. 17-23.

11 See Blackaby/Partasides et al., (fn. 4), p. 590 et seq. 
proceeding - the selected foreign law and the lex arbitri and its mandatory provisions. Additionally, complications would arise during the arbitral conduct when court assistance is needed, as it will not be clear which court should perform the task and under which law. The court at the seat would probably be unwilling to provide assistance under foreign procedural law, whereas the court whose country's procedural law was chosen could be unwilling to rule on a matter outside its territorial jurisdiction. ${ }^{12}$ Moreover, although challenges in courts other than that at the seat of arbitration are theoretically possible, such challenges are generally rejected. ${ }^{13}$

\section{The purpose and effect of recourse against an arbitral award}

The possibility of challenging arbitral awards has been deemed a "bulwark against corruption, arbitrariness [and] bias", ${ }^{14}$ constituting a safeguard against erroneous decisions which would otherwise have a binding legal effect on the parties. In general, it enhances parties' confidence into the arbitral process. From the perspective of the losing party, however, the ultimate purpose of recourse against an award is to have the award modified or annulled, in whole or in part, in the jurisdiction where the award was rendered. ${ }^{15}$ In the event of a successful challenge, the award would be invalid and hence unenforceable at the seat of arbitration. ${ }^{16}$ Additionally, the same effect could be achieved in other jurisdictions, since the New York Convention leaves it to the discretion of the competent authority to decide whether to refuse or accept the recognition or enforcement of the award previously set aside or suspended by the court at the seat of arbitration. ${ }^{17}$

\section{A general trend towards limiting court intervention}

The approach towards arbitration has undergone a significant change over the last century. Historically, national laws allowed for the possibility of extensive court interference in arbitral proceedings and courts were generally inclined to deny arbitration, creating an "arbitration unfriendly" environment. ${ }^{18}$ Furthermore, national courts generally had wide powers to review merits of awards, leading to a so-called "judicial second-guessing". ${ }^{19}$ Yet this attitude gradually began to change, so that these days arbitration and party autonomy experience wide-spread acceptance. ${ }^{20}$

12 See ibid., p. 184 et seq.

13 See Lew/Mistelis/Kröll, (fn. 3), p. 666 et seq.

14 Kerr, Arbitration and the Courts: The UNCITRAL Model Law, Int'l \& Comp. L.Q. 34 (1985), p. 15.

15 See Blackaby/Partasides et al., (fn. 4), p. 584 et seq.

16 See ibid., p. 585; Lew/Mistelis/Kröll, (fn. 3), p. 664.

17 Article V(1)(e) of the New York Convention.

18 See Born, (fn. 1), pp. 36, 39-41, 45-47, 50-52, 60-61.

19 See Garcia, Is the Principle of Finality "Losing Its Appeal"?, Kluwer Arbitration Blog of $18 / 5 / 2011$.

20 See Lew/Mistelis/Kröll, (fn. 3), p. 355; UNCITRAL Secretary-General, Report of the SecretaryGeneral: Possible features of a model law on international commercial arbitration, A/CN.9/207, 1981, para. 103. 
Nowadays, the general trend when it comes to international arbitration is to limit court intervention to the utmost. ${ }^{21}$ Extensive court interventions can negatively affect the arbitral proceeding, leading to disruption and prolongation contrary to parties' wishes for an effective and time-efficient arbitral process. ${ }^{22}$ The trend of limiting court involvement can, for instance, be seen in the changes of the "special case procedure" in England. ${ }^{23}$ At the outset, this procedure essentially provided for an appeal on any point of law, without the possibility to exclude it. With the Arbitration Act 1979, this procedure was significantly limited, but completely abolished by the Arbitration Act 1996, which currently allows an appeal on questions of English law only in limited situations. ${ }^{24}$ This trend of limiting court involvement is furthermore reflected in Article 5 of the Model Law, which states that in matters governed by the Model Law

"[...] no court shall intervene except where so provided in this Law". ${ }^{25}$

\section{Limiting recourse against an arbitral award to the setting aside procedure}

As regards court intervention in the post-award stage, the majority of national arbitration laws provide for a setting aside procedure. The grounds for setting aside arbitral awards are generally limited to major procedural deficiencies, arbitrability and public policy considerations, thus mirroring the grounds for non-recognition and non-enforcement of the award under Article V of the New York Convention. ${ }^{26}$ These grounds are: (1) a party's lack of capacity to conclude the arbitration agreement or invalidity of the agreement; (2) the party was not given proper notice of the appointment of arbitrators or of the proceeding or was otherwise unable to present its case; (3) the award deals with a dispute outside the terms of the submission to arbitration; (4) the composition of the arbitral tribunal or the arbitral procedure was not in accordance with the agreement of the parties or, absent of such an agreement, with the law of the seat of arbitration; (5) the subject-matter of the dispute is non-arbitrable; or (6) the award is in conflict with local public policy.

\section{No review on the merits in a setting aside procedure}

The grounds for setting aside an award are, as stated above, limited to matters of jurisdiction, procedural deficiencies, arbitrability and public policy. ${ }^{27}$ Parties thus have no right to challenge an award based on alleged mistakes of law or fact and the court has no power to review the merits of the case. Hence, a setting aside procedure must be distinguished from a review on the merits (also called an "appeal procedure").

21 See Lew/Mistelis/Kröll, (fn. 3), p. 354; Blackaby/Partasides et al., (fn. 4), p. 615 et seq.

22 See Lew/Mistelis/Kröll, (fn. 3), p. 357.

23 For more information see ibid., pp. 355-358.

24 Section 69 of the English Arbitration Act 1996.

25 See Lew/Mistelis/Kröll, (fn. 3), p. 357.

26 See Born, (fn. 1), p. 3164 et seq.; Lew/Mistelis/Kröll, (fn. 3), p. 372 et seq.

27 See Moses, (fn. 7), p. 207. 
In appeal procedures evidence is re-evaluated and the correctness of a tribunal's decision on the merits is examined, which is not the case under the setting aside procedure. ${ }^{28}$ Furthermore, in an appeal procedure the court can alter the content of the award and impose a different outcome on the parties. ${ }^{29}$

By contrast, when dealing with an application to set aside an award, the court only considers whether a ground for annulment is present. The court can either reject the challenge and uphold the award or accept the challenge and annul the award, fully or partially. In some jurisdictions, the court will also have the opportunity to remit the award to the arbitral tribunal for reconsideration. ${ }^{30}$ However, unlike in the appeal procedure, the court cannot alter the content of the award and substitute the award with its own decision, as it does not have jurisdiction to decide on the merits of the case. Hence, the commonly accepted standard of judicial review does not encompass a review on the merits ${ }^{31}$ and should not be confused therewith.

\section{No review on the merits when setting aside on grounds of "public policy"}

Violation of local public policy is a ground for setting aside an award under most arbitration laws. ${ }^{32}$ This ground, despite the general view that courts cannot review the merits of the case in setting aside procedures, has raised a number of questions due to a failure to define the term and its content. ${ }^{33}$ Nonetheless, states have generally taken a restrictive approach to public policy, limiting its application to cases of the most fundamental procedural and substantive injustice. ${ }^{34}$

28 See e.g., High Court of Singapore of 17/11/2006, OM 3/2005, Government of the Republic of the Philippines v. Philippine International Air Terminals Co., [2006] SGHC 206, para. 38: "An arbitral award was not liable to be struck down because it was premised on incorrect grounds whether of law or fact. An application to set aside an award under the IAA was not an appeal on the merits and could not be considered in the same way." Accord High Court at Nairobi of 24/11/2005, Misc Appli 241 of 2005, Apa Insurance Co. Ltd. v. Chrysanthus Barnabas Okemo; Amman Court of Appeals of 10/6/2008, case no. 206/2008, available in: International Journal of Arab Arbitration 2 (2010), p. 136; Madrid Court of Appeal of 20/1/2006, case no. 19/2006, Sofia v. Tintorería Paris, available in: UNCITRAL, 2012 Digest of Case Law on the Model Law on International Commercial Arbitration, 2012, p. 135, para. 3. See also Born, (fn. 1), pp. 3351-3353.

29 See ibid., p. 3160.

30 See e.g., Article 34(4) of the Model Law; section 69 of the English Arbitration Act 1996. See also section 1059(4) of the German ZPO, which foresees remittance of the case to the tribunal after the court has set aside the award.

31 See Blackaby/Partasides et al., (fn. 4), p. 608; Moses, (fn. 7), p. 207; Fisher, Appeals on Questions of Law, First Annual New Zealand Arbitration Day, Auckland on 9/6/2006, para. 45.

32 See e.g., Article 34(2)(b)(ii) of the Model Law; Article 190(2)(e) of the Swiss PILA; section 68(2) (g) of the English Arbitration Act 1996; section 1059(2)(2)(b) of the German ZPO; Article 1065(1) (e) of the Code of Civil Procedure Netherland.

33 Some countries however explicitly state what public policy violation consists of (see e.g., Article 34(6) of the New Zealand Arbitration Act 1996, Article 58 of the Malta Arbitration Act, section 19 of the Australia International Arbitration Act 1974 or section 24 of the Singapore International Arbitration Act).

34 See Blackaby/Partasides et al., (fn. 4), p. 613; Born, (fn. 1), p. 3321; UNCITRAL, (fn. 28), p. 159 et seq., para. 129. 
Some important guidance in defining public policy was provided by UNCITRAL in its Report: ${ }^{35}$

"In discussing the term 'public policy', it was understood that it was not equivalent to the political stance or international policies of a State but comprised the fundamental notions and principles of justice." 36

"Thus, instances such as corruption, bribery or fraud and similar serious cases would constitute a ground for setting aside. It was noted, in that connection, that the wording 'the award is in conflict with the public policy of this State' was not to be interpreted as excluding instances or events relating to the manner in which an award was arrived at." 37

Nevertheless, due to the imprecise nature of public policy, some parties and courts attempt to use it as a back door in order to review the merits of the dispute. ${ }^{38}$ For this reason, one must underline that courts, when deciding whether there is a violation of public policy, do not have the power to review the merits. ${ }^{39}$ The courts only examine whether the award as a whole violates matters of public policy, a conclusion confirmed by jurisprudence. ${ }^{40}$

\section{Contractual extension of judicial review - do parties have a right thereto?}

As previously stated, national arbitration laws generally contain restricted grounds for challenging an award and it will therefore be far from easy for a party confronted with an unfavorable award to get that award annulled. As a result of these difficulties, parties may decide to provide for a more extensive judicial review in their arbitration agreement, going beyond what is available under national law. The rationale behind this may differ, ${ }^{41}$ but usually it is parties' fear that "a maverick arbitrator will render an egregious award, which cannot be challenged even though wrong on the facts and the law". ${ }^{42}$ Where parties contractually expand judicial review, the question arises as to whether such agreements are valid.

35 UNCITRAL, Report of the United Nations Commission on International Trade Law on the work of its eighteenth session, $\mathrm{A} / 40 / 17,1985$.

36 See ibid., para. 296.

37 See ibid., para. 297.

38 See Blackaby/Partasides et al., (fn. 4), p. 614.

39 See Born, (fn. 1), p. 3325 et seq.

40 See e.g., Madrid Court of Appeal of 22/3/2006, case no. 178/2006-4/2004, Uniprex S.A. v. Grupo Radio Blanca, available in: UNCITRAL, (fn. 28), p. 141, para. 26, fn. 662; Supreme Court of Canada of 31/3/2003, Docket 28660, Desputeaux v. Éditions Chouette (1987) Inc., [2003] 1 S.C.R. 178, p. 5. See also fn. 28.

41 See Cole, Revising the FAA to Permit Expanded Judicial Review of Arbitration Awards, Nev.L.J. 8 (2007), pp. 215-218; Barcelo III, Expanded Judicial Review of Awards After Hall Street and in Comparative Perspective, in: Hay/Vékás/Elfana et al. (eds.), Resolving International Conflicts: Liber Amicorum Tibor Várady, 2009, pp. 7-9.

42 Moses, Can Parties Tell Court What to Do?, Expanded Judicial Review of Arbitral Awards, U. Kan. L. Rev. 52 (2004), p. 429. 


\section{Mandatory rules as a limitation on parties' freedom to contract}

Although arbitration is considered a private method of dispute settlement with party autonomy being one of its key principles, parties' contractual freedom is not unlimited. Party autonomy is subject to mandatory rules of law that serve to protect states' public interests. ${ }^{43}$ Therefore, in order to decide whether parties' agreement to expand the judicial review is valid, one must first decide on the default or mandatory nature of the provision. If the provision dealing with recourse against an award is a default provision, the parties are free to deviate therefrom and can, therefore, contractually expand judicial review. By contrast, if the provision is mandatory, the parties cannot deviate therefrom and agreements expanding judicial review are invalid.

As previously noted, a party wishing to have an award re-evaluated must bring an action in the court at the seat of arbitration. Consequently, the law governing this action will be the law of the seat. ${ }^{44}$ Thus, when evaluating the validity of parties' agreement to expand judicial review, regard must be had to the mandatory rules of the lex arbitri.

Whether a provision constitutes a default or mandatory provision depends on how it is interpreted. ${ }^{45}$ When interpreting legal provisions, significant tensions exist between an interpretation based on the exact wording (textual or literal method) and an interpretation aimed at finding the law's true intention (subjective, contextual, teleological or holistic method). ${ }^{46}$ The textual method of interpretation is based on the assumption that the real meaning of a provision can be deduced solely from its wording. ${ }^{47}$ Conversely, the subjective approach presumes that the goal of interpretation is to adhere to the real intention of the drafters and see what they wanted to achieve with the provision. ${ }^{48}$ Notably though, none of these methods of interpretation exclude one another and they can be used as complementary means of interpretation. Yet it is up to the interpreter which methods will be applied, unless the law itself prescribes something else. ${ }^{49}$

Nonetheless, a mandatory rule is justified only if it serves to protect the parties to the contract or third parties - otherwise it should be a default rule. ${ }^{50}$

\section{Party autonomy and the finality of an award}

Prior to addressing whether agreements expanding judicial review are valid, reference should be made to the core principles of arbitration, as they play an important role in judicial reasoning as well as in academia. Typical definitions of arbitration encompass two basic

43 See Lew/Mistelis/Kröll, (fn. 3), p. 27; Blackaby/Partasides et al., (fn. 4), p. 204, para. 3.128.

44 See Moses, (fn. 7), p. 203.

45 See Drahozal, Contracting Around RUAA: Default Rules, Mandatory Rules, and Judicial Review of Arbitral Awards, Pepp. Disp. Resol. L. J. 3 (2003), p. 421.

46 See Murray, Methods of interpretation - Comparative Law method, in: Actes du colloque pour le cinquantieme anniversaire des Traités de Rome, 26 March 2007, p. 39.

47 See Bredimas, Methods of Interpretation and Community Law, 1978, p. 15.

48 Ibid., p. 17 et seq.; Cassese, International Law, 2nd ed. 2005, p. 178.

49 See Kelsen, Principles of International Law, 2003, p. 321.

50 See Drahozal, (fn. 45), p. 421 - citing Ayres, Default Rules for Incomplete Contracts, in: Newman (ed.), The New Palgrave Dictionary of Economics and the Law, Vol. 1, 1998, p. 586. 
elements: the contractual element and the judicial element. ${ }^{51}$ The contractual element takes the agreement of the parties as the basis for arbitration, also referred to as the principle of party autonomy. The judicial element is the task of the arbitral tribunal to resolve the dispute by means of a binding and final decision, an element reflected in the principle of finality.

The principles of party autonomy and finality will normally not collide. However, when parties contractually expand the judicial review available under national arbitration law, these principles will potentially contradict one another and thus, debate ensues as to which principle should prevail. For this reason it is important to understand each of their meanings.

\section{Party autonomy}

Arbitration is a creature of parties' consent and party autonomy indisputably constitutes a key principle of international commercial arbitration. Arbitration is a result of parties' consent; it evolves from an agreement between the parties and develops by way of private proceedings. ${ }^{52}$ Party autonomy influences each stage of the arbitral procedure, providing the parties with an enormous amount of flexibility. ${ }^{53}$

The exercise of this autonomy falls into two main categories. ${ }^{54}$ The first of these entails parties' right to submit their dispute to arbitration and to define its scope by way of an arbitration clause ${ }^{55}$ or a submission agreement. ${ }^{56}$ The second involves parties' right to determine the conduct of arbitral proceedings, either directly in their agreement or indirectly by reference to adequate arbitration rules. This freedom gives them the possibility to eschew the formalities of a state court's procedure and to tailor it to a particular dispute. ${ }^{57}$ This flexibility is one of the attractions of arbitration. ${ }^{58}$

\section{Finality of an award}

The second characteristic of arbitration is the finality of an arbitral award. According to the principle of finality, arbitration is a mechanism for the final and binding determination of disputes and by deciding to refer their disputes to arbitration, parties accept that they will respect and give effect to the arbitral award..$^{59}$ Arbitration results in a binding resolution of a dispute in the form of an award and it can thus be distinguished from other methods of

51 See Gaillard/Savage, Fouchard Gaillard Goldman On International Commercial Arbitration, 1999, p. 10, para. 11; Wolff, Party Autonomy to Agree on Non-Final Arbitration?, ASA Bulletin 3/2008, p. 626.

52 See Blackaby/Partasides et al., (fn. 4), p. 29, para. 1.84; Born, (fn. 1), p. 83; Lew/Mistelis/Kröll, (fn. 3), p. 3; Moses, (fn. 7), p. 1 et seq.; Gaillard/Savage, (fn. 51), p. 30; Poudret/Besson, Comparative Law of International Arbitration, 2nd ed. 2007, p. 3, para. 4.

53 See Born, (fn. 1), p. 83; Gaillard/Savage, (fn. 51), p. 31, para. 51.

54 See Wolff, (fn. 51), p. 632.

55 Parties agree to submit their disputes to arbitration before a dispute has arisen. See Blackaby/ Partasides et al., (fn. 4), p. 14, para. 1.38 et seq.

56 Parties agree to submit their disputes to arbitration after a dispute has arisen, see ibid.

57 See Born, (fn. 1), pp. 83-85.

58 See Lew/Mistelis/Kröll, (fn. 3), p. 3; Born, (fn. 1), p. 84.

59 See e.g., Lew/Mistelis/Kröll, (fn. 3), pp. 1-4; Born, (fn. 1), p. 82. 
alternative dispute resolution such as mediation and conciliation. These endeavor to bring the parties together and help them in finding a solution but neither the mediator nor the conciliator can impose a solution on the parties. The solution will only become binding if the parties agree to such a solution in the form of a settlement. ${ }^{60}$

Having addressed the concept of recourse against an award in state courts, the notion of expanded judicial review, its limits and key factors influencing the right to expand the judicial review, this paper will now elaborate in more depth on the possibility of expanding judicial review under the Model Law (with reference to jurisprudence in Model Law countries) and under the United States Federal Arbitration Act.

\section{Judicial review and parties' right of expansion under the UNCITRAL Model Law on International Commercial Arbitration}

A better understanding of the potential recourse against an award and parties' right of expansion under the Model Law is essential to a complete analysis of this topic for several reasons. The Model Law was adopted on 21 June 1985 by UNCITRAL and it represents, as the wording indicates, a model that can be adopted by national legislators verbatim or partially. ${ }^{61}$ It contains a complete set of rules covering all stages of the arbitral procedure, which are the result of extensive consultations of interested international organizations, arbitration experts and different governments, ${ }^{62}$ reflecting "a worldwide consensus on the principles and important issues of international arbitration practice". ${ }^{63}$ As such, the Model Law is acceptable to all States, independent of their legal system, ${ }^{64}$ and United Nations Member States are advised to implement this model. ${ }^{65}$ Indeed, the Model Law today forms the basis of more than sixty states' arbitrations laws, ${ }^{66}$ a point which clearly evidences its great success.

60 See Gaillard/Savage, (fn. 51), p. 11, para. 16.

61 See Binder, International Commercial Arbitration and Conciliation in UNCITRAL Model Law Jurisdictions, 2nd ed. 2005, p. 11, para. 1-008.

62 See Roth, UNCITRAL Model Law on International Commercial Arbitration, in: Weigand (ed.), Practitioner's Handbook on International Commercial Arbitration, 2nd ed. 2009, p. 955 et seq., paras. 14.09-14.14.

63 UNCITRAL Secretariat, (fn. 9), para. 2. See also Herrmann, The UNCITRAL Model Law on International Commercial Arbitration: Introduction and General Provisions, in: Šarčević (ed.), Essays on International Commercial Arbitration, 1989, p. 16 et seq.

64 See Binder, (fn. 61), p. 8, para. 1-002; Lemay/Montineri, Review of the Model Law's Implementation after Twenty Five Years, in: Bachand/Gélinas (eds.), The UNCITRAL Model Law After 25 Years: Global Perspectives on International Commercial Arbitration, 2013, p. 4 et seq.

65 See UN General Assembly, General Assembly Resolution A/RES/40/72 of 11/12/1985; Binder, (fn. 61), p. 8, para. 1-002; Blackaby/Partasides et al., (fn. 4), p. 75, para. 1.232.

66 For the list of states that adopted the UNCITRAL Model Law see www.uncitral.org/uncitral/en/ uncitral_texts/arbitration/1985Model_arbitration_status.html (1/10/2014). 


\section{Relevant provisions and possible interpretations}

Article 5 of the Model Law states that

"[i]n matters governed by this Law, no court shall intervene except where so provided in this Law".

The possible recourse against an arbitral award is set out in chapter VII of the Model Law, a chapter which only encompasses one article, namely Article 34 dealing with the setting aside procedure. This provision, labeled "Application for setting aside as exclusive recourse against award", states in its first paragraph that:

"Recourse to a court against an arbitral award may be made only by an application for setting aside in accordance with paragraphs 2 and 3 of this article."

The second paragraph contains the list of grounds for setting aside, which can be divided into two groups. Article 34(2)(a) refers to grounds that have to be proven by the party submitting the application for setting aside (in the list below grounds (1)-(4)), while Article 34(2)(b) comprises grounds that have to be examined ex officio (grounds (5) and (6)). ${ }^{67}$ The ground for setting aside are exhaustively enumerated ${ }^{68}$ and are as follows:

(1) a party to the arbitration agreement was under some incapacity or the said agreement was invalid;

(2) a party was not given proper notice or was otherwise unable to present its case;

(3) the award deals with a dispute outside the terms of the submission to arbitration;

(4) the composition of the arbitral tribunal or the arbitral procedure was not in accordance with the agreement of the parties;

(5) the subject-matter of the dispute is non-arbitrable; or

(6) the award is in conflict with the local public policy.

The setting aside procedure and its grounds do not encompass a review on merits. ${ }^{69} \mathrm{Nev}$ ertheless, the Model Law's provisions neither explicitly qualify Article 34 as mandatory nor clearly bar parties from expanding judicial review. One therefore has to undertake a certain amount of interpretation in order to make a determination as regards the validity of parties' agreement to expand judicial review. As previously mentioned, there is a tension between the textual and subjective method of interpretation and, ideally, these methods would be used as complementary means of interpretation. Nonetheless, if one were to categorically refuse such an approach and apply only one method, different conclusions could be arrived at depending on the interpretation method used. For this reason, the following will address the textual as well as subjective interpretation of Article 34 of the Model Law.

67 See Binder, (fn. 61), p. 273, para. 7-017.

68 See Gharavi, Achievements and Limits of the UNCITRAL Model Law's Annulment Regime, in: Association for International Arbitration (ed.), The UNCITRAL Model Law on International Commercial Arbitration: 25 years, 2010, p. 136; Roth, (fn. 62), p. 1102, para. 14.525; Gharavi, (fn. 9), p. 31.

69 See B.IV. and fn. 28 above. See also Binder, (fn. 61), p. 271, para. 7-008; Gharavi, (fn. 9), p. 30. 


\section{Textual interpretation}

Should one exclusively employ the textual method of interpretation when analysing the nature of Article 34 of the Model Law, it is easy to come to the conclusion that the provision is mandatory.

This follows from the heading of the provision itself, which states that the setting aside procedure is the exclusive recourse against award. Moreover, Article 34 states that recourse to a court against an award "may be made only by an application for setting aside". The use of the word "only" further underlines the mandatory nature of Article 34, clarifying that there is no other means of recourse to a court except the setting aside procedure. The mandatory nature could likewise be derived from Article 5 of the Model Law: use of the wording "no court shall" excludes any additional court involvement apart from that provided for in the Law itself and Article 34 is the only provision which deals with recourse against arbitral awards by means of setting aside proceedings. Thus, on a purely textual approach, Article 34 of the Model Law would be viewed as a mandatory provision.

\section{Subjective interpretation}

Naturally, it is questionable whether a determination based purely on a textual approach is justifiable. Indeed, one could quite easily conclude that a purely textual approach does not suffice and that one should therefore make use of the subjective method, which also takes the objective and purpose of the Model Law into account.

The importance of considering the objective and purpose of a legal act whilst interpreting ambiguous provisions is widely accepted ${ }^{70}$ and is particularly endorsed in the Vienna Convention on the Law of Treaties. ${ }^{71}$ Although applicable to international treaties, the Vienna Convention's rules on interpretation are equally suitable for the interpretation of a transnational model law, reflecting as they do the well-established customary rule of interpretation. $^{72}$

In ascertaining the objective and purpose of the law, the drafting history can provide valuable guidance and should therefore be taken into account. The importance of the travaux préparatoires can be deduced, although indirectly, by an interpretation of Article $2 \mathrm{~A}$ of the Model Law, which was included during the amendments in $2006 .{ }^{73}$ This provision seeks to facilitate interpretation and "promote a more uniform understanding" 74 by reference to its international origin, the need to promote uniformity and general

70 See Bachand, Judicial Internationalism and the Interpretation of the Model Law: Reflections on some Aspects of Article 2A, in: Bachand/Gélinas, (fn. 64), p. 234 et seq.

71 Article 31 of the Vienna Convention on the Law of Treaties (hereinafter: Vienna Convention) calls for an interpretation in the light of the object and purpose of the treaty.

72 See Bachand, (fn. 70), pp. 242-244.

73 See UNCITRAL, Report of the United Nations Commission on International Trade Law on the work of its thirty-ninth session, A/61/17, 2006, para. 174 et seq.

74 Ibid., para. 175. 
principles on which the Law is based. ${ }^{75}$ The wording of Article 2A is almost identical to Article 7 of the United Nations Convention on Contracts for the International Sale of Goods $^{76}$ and thus judicial interpretations of the latter can and should be taken into account when defining the scope of Article 2A. According to these court decisions, reference to the drafting history when interpreting a provision is permissible. ${ }^{77}$ The general importance of the travaux préparatoires when interpreting legal provisions is furthermore confirmed by scholars, ${ }^{78}$ courts ${ }^{79}$ and arbitration laws. ${ }^{80}$ Most importantly, however, the drafters themselves highlighted the importance of the travaux préparatoires when clarifying the Model Law. ${ }^{81}$ For these reasons, one can justifiably make use of the subjective method of interpretation, taking into account the purpose and objective of the Model Law when interpreting its provisions.

In doing so, one would arrive at a different conclusion when analyzing Article 34 of the Model Law than when merely using the textual approach, namely that it is a default rule, resulting in parties being able to deviate therefrom by way of private agreement.

75 Article 2A of the Model Law states: "(1) In the interpretation of this Law, regard is to be had to its international origin and to the need to promote uniformity in its application and the observance of good faith. (2) Questions concerning matters governed by this Law which are not expressly settled in it are to be settled in conformity with the general principles on which this Law is based."

76 The United Nations Convention on Contracts for the International Sale of Goods is adopted in 1980 in Vienna and is commonly referred to as the CISG. Article 7 of the CISG reads as follows: "(1) In the interpretation of this Convention, regard is to be had to its international character and to the need to promote uniformity in its application and the observance of good faith in international trade. (2) Questions concerning matters governed by this Convention which are not expressly settled in it are to be settled in conformity with the general principles on which it is based or, in the absence of such principles, in conformity with the law applicable by virtue of the rules of private international law."

77 District Court Aachen of 20/7/1995, 41 O 111/95 (referring to the drafting history of Article 78 CISG); Appellate Court Frankfurt of 20/4/1994, 13 U 51/93, New Zealand Mussels case: "the court observed that the latter seems correct, because during the negotiation of CISG a Canadian proposal concerning average quality was withdrawn". See also UNCITRAL, Digest of case law on the United Nations Convention on the International Sale of Goods, A/CN.9/SER.C/DIGEST/ CISG/7, p. 2, para. 2 and fn. 6.

78 See e.g., Binder, (fn. 61), p. 10 et seq.; Roth, (fn. 62), p. 980, para. 14.16; Bachand, (fn. 70), pp. 249-251.

79 See e.g., Court of Appeal Singapore of 26/2/2008, CA 47/2007, NCC International AB v. Alliance Concrete Singapore Pte Ltd., [2008] SGCA 5, para. 31: "We then considered the drafting history of sections 12(1) and 12(7) of the IAA". British Columbia Court of Appeal of 24/10/1990, Doc. Vancouver CA012636, Quintette Coal Limited v. Nippon Steel Corp., [1991] 1 W.W.R. 219, p. 8: "[t]he starting point in the construction exercise is an understanding of the historical setting of the C.C.A.A. to the end that section 11 is read in such a manner as to achieve the object of Parliament".

80 See e.g., section 4 of the Commercial Arbitration Act of Canada: "In interpreting the Code, recourse may be had to (a) the Report of the United Nations Commission on International Trade Law on the work of its eighteenth session, held from June 3 to 21, 1985; and (b) the Analytical Commentary contained in the Report of the Secretary General to the eighteenth session of the United Nations Commission on International Trade Law". See also section 17 of the Australia International Arbitration Act 1974; section 3 of the New Zealand Arbitration Act 1996; section 4(1) of the Singapore International Arbitration Act or section 24 of the Bermuda International Conciliation and Arbitration Act 1993.

81 See UNCITRAL, (fn. 35), para. 60. 
The principle of party autonomy is, together with the principle of equality, deemed the most important principle of the Model Law and has even been referred to as the "Magna Carta of arbitral procedure". ${ }^{82}$ When the drafting process was initiated, it was decided that the Model Law should provide a "constitutional framework" which would "recognize the parties' free will and the validity and effect of their agreement based thereon". ${ }^{83}$ Party autonomy's central role has been confirmed by the UNCITRAL Secretariat ${ }^{84}$ as well as the Secretary-General, who stated that freedom of the parties is "probably the most important principle on which the model law should be based", ${ }^{85}$ with which the Working Group agreed. ${ }^{86}$

The importance of party autonomy is further underlined by the raison d'être of the Model Law, namely that of resolving one of the earlier main complaints that mandatory provisions of the applicable law often frustrated the will and expectations of the parties. ${ }^{87}$ Thus, it was suggested that party autonomy should only be limited by mandatory provisions "designed to prevent or to remedy certain major defects in the procedure, any instance of denial of justice or violation of due process" 88 thereby paving the way for greater recognition of parties' agreement and expectations.

As regards the rationale behind the limited form of court intervention under the Model Law, the UNCITRAL Secretariat stated that it consisted in protecting the arbitral process from "unpredictable and disruptive court interference", which is "essential to parties who choose arbitration" ${ }^{89}$ Accordingly, the purpose of Article 34 of the Model Law is to protect the parties from undesired court intervention in the post-award stage and in that way respect parties' agreement and expectations. Yet in case where parties make a conscious decision to dispense with such protection and instead include a higher degree of court scrutiny, parties should be free to do so.

For a correct interpretation of Article 34 of the Model Law, an analysis of Article 5 of the Model Law is of necessity, particularly as some view Article 5 as not only restricting court intervention, but also as denying parties the possibility to contract for an expanded judicial review. ${ }^{90}$ True, parties' possibility to expand judicial review was discussed by the Commission after a proposal to give them that possibility, but the Commission eventually dismissed the proposal and adopted Article 5 in its current form. ${ }^{91}$ This dismissal cannot, however, be taken to categorically mean that parties should be denied the right to expand the judicial review. In its report, the Commission expressed concerns about parties' ability

82 UNCITRAL Secretary-General, Analytical Commentary on Draft Text of a Model Law on International Commercial Arbitration, A/CN.9/264, 1985, p. 44, Article 19 para. 1. See also Binder, (fn. 61), p. 185.

83 UNCITRAL Secretary-General, (fn. 20), para. 18.

84 UNCITRAL Secretariat, (fn. 9), para. 31.

85 UNCITRAL Secretary-General, (fn. 20), para. 17.

86 See Working Group on International Contract Practices, Report of the Working Group on International Contract Practices on the Work of its Third Session, A/CN.9/216, 1982, para. 14.

87 See UNCITRAL Secretary-General, (fn. 20), para. 10; UNCITRAL Secretariat, (fn. 9), para. 7.

88 UNCITRAL Secretary-General, (fn. 20), para. 19.

89 See UNCITRAL Secretariat, (fn. 9), para. 17.

90 See Wolff, (fn. 51), p. 635.

91 See UNCITRAL, (fn. 35), para. 64 et seq.; Roth, (fn. 62), p. 980, para. 14.103. 
to draft an adequate agreement and the risk of subjecting parties to court intervention they had not expected in the event of institutional arbitration rules including a provision expanding the right of court intervention. ${ }^{92}$ These concerns are, however, unjustified. The former is highly speculative, as it will vary from case to case and should therefore not be taken as a general reason for disallowing parties to contractually agree on expanded judicial review. The latter concern deals with the situation of court intervention not expected by the parties. However, where parties willingly agree to expand judicial review, no element of surprise exists, rendering the concern obsolete.

Another important point that cannot be disregarded is the compatibility of expanded judicial review with the principle of finality, the former potentially contravening the latter. Such a concern, however, proves unfounded. Finality of the award implies exclusion of any means by which parties can go against it. In order to comply with this principle, arbitration has to be the first and only step taken by the parties. ${ }^{93}$ It should be noted that the Model Law, by providing for a setting aside procedure, itself places a condition on finality, thereby prioritizing recourse against an award. One could consider that the setting aside procedure does not go against the finality of award due to the limited grounds of challenge and only a review on merits is contrary to it. In such a case, the possibility of any review on merits would have to be excluded. However, appealing to an arbitral tribunal is allowed if parties have expressly agreed to it ${ }^{94}$ despite being considered a departure from the principle of finality. ${ }^{95}$ Parties enjoy fully-fledged freedom as regards the arbitral appeal and can therefore decide to nominate a completely new panel to review the merits. Should parties so decide, the panel's rights would in no way differ from those of a court reviewing the merits, meaning the effect on arbitral awards would be the same. For these reasons, a review on merits cannot be viewed as antithetical to the principle of finality. Even if one were to find that the two conflict though, party autonomy should prevail, because the Model Law endorses the enforcement of arbitration agreements according to the agreed upon terms. Indeed, the Model Law functions to "promote the efficient conduct of international arbitration", with parties being free to solve their disputes "in the manner which suit [...] them best". ${ }^{96}$ With party autonomy being the foundation of arbitration, parties should be free to opt for legal certainty by having a review on the merits at the expense of the award being final.

Classifying Article 34 of the Model Law as a mandatory provision would these days run counter to the drafters' original intentions. Article 34 is geared towards protecting parties from unnecessary court involvement, but not preventing parties from exercising their right to expand judicial review. Therefore, Article 34 of the Model Law should be seen as a default provision from which parties can deviate by way of their private agreement.

92 See UNCITRAL, (fn. 35), para. 64.

93 See Court of Appeal Singapore of 26/8/2009, CA 171/2008, Suit 348/2008, Tjong Very Sumito and Others v. Antig Investments Pte Ltd., [2009] 4 SLR 732, p. 29: "Arbitration is not viewed by commercial persons as simply the first step on a tiresome ladder of appeals. It is meant to be the first and only step". Accord Born, (fn. 1), p. 72.

94 See UNCITRAL Secretariat, (fn. 9), para. 45.

95 See Born, (fn. 1), p. 3162.

96 UNCITRAL, 305th Meeting - General observations on the draft text of a model law on international commercial arbitration, 1985, para. 8. 


\section{Judicial decisions in Model Law jurisdictions}

As demonstrated, one can come to differing conclusions as to the nature of Article 34 simply by employing different methods of interpretation. These constitute purely theoretical methods of analysis though, and in practice it is up to the courts which approach to take and whether they will grant parties the right to expand judicial review.

As far as Model Law jurisdictions are concerned, courts primarily view Article 34 as mandatory, meaning parties cannot contractually provide for judicial review on the merits. Due to this paper's limited scope, only a small number of court decisions denying parties the right to expand judicial review will be referred to, with the focus then shifting to the well-known exception of allowing parties to expand judicial review by providing an analysis of the decision and its criticism.

\section{Rulings prohibiting expanded judicial review}

Although the majority of courts in Model Law jurisdictions find parties' agreements to expand judicial review invalid, they differ in their reasoning.

The appellate court of New Zealand, albeit obiter dicta, opined that parties are not free to agree on further-reaching judicial review due to the "exclusionary terms" of Article 34 of the New Zealand Arbitration Act, thereby relying on the textual features of the law. ${ }^{97}$ With the same reasoning, the Indian Supreme Court considered

"that the parties could not question the validity of an award in proceedings other than in setting aside proceedings". ${ }^{98}$

The appellate court of New Zealand's recent judgement in Gallaway Cook Allen v. Carr confirmed that parties are not allowed to expand judicial review under the New Zealand Arbitration Act, but stated that this follows from Parliament's intention to give effect to the finality of award and limit court interventions. ${ }^{99}$ The Federal Court of Canada also emphasised the finality of awards and held that Article 34 of the Commercial Arbitration Code does not allow for judicial review of law or fact and that a contrary conclusion would result in arbitration merely amounting to a first step and that

"the speed and, above all, the finality of the arbitral process is lost". ${ }^{100}$

97 Court of Appeal New Zealand of 17/6/2004, Methanex Motunui Ltd. v. Spellman, [2004] 3 NZLR 454, available in: UNCITRAL, (fn. 28), p. 135, para. 8, fn. 618.

98 Supreme Court India of 9/5/2006, M/S. Centrotrade Minerals \& Metal. Inc. v. Hindustan Copper, [2006] INSC 293, available in: UNCITRAL, (fn. 28), p. 135 et seq., para. 8, fn. 619.

99 Court of Appeal New Zealand of 15/2/2013, CA437/2012, Gallaway Cook Allen v. Ewan Robert Carr, [2013] NZCA 11, para. 46.

100 Federal Court Canada of 13/1/2004, T-225-01, T-81-03, Canada (Attorney General) v. S.D.Myers Inc., 2004 FC 38, para. 42. 
The Supreme Court of Quebec highlighted that the court has no power to review the award, as Article 5 of the Model Law excludes all court interventions except as provided for in the law itself. ${ }^{101}$

\section{Ruling allowing an expanded judicial review}

Despite this tendency of rejecting expanded judicial review, the German Supreme Court reached an entirely different conclusion in 2007. ${ }^{102}$ However, before turning to the reasoning provided for in the decision, one should note that the German Supreme Court was dealing with a domestic arbitration case and applied domestic arbitration law. Nonetheless, this does not render the decision irrelevant for international arbitration, for section 1025 of the Code of Civil Procedure (ZPO) explicitly provides for the application of ZPO provisions in international arbitral proceedings if the tribunal is seated in Germany. ${ }^{103}$ The Tenth Book of the ZPO, labeled "Arbitration Proceeding" and which is to a large extent a verbatim adoption of the Model Law, ${ }^{104}$ applies to international as well as domestic arbitration. ${ }^{105}$ Furthermore, the reasoning of the German Supreme Court is not restricted solely to the provisions of the law but rather takes the nature of arbitration into account when deciding on the issue. For these reasons, the decision can be seen as relevant in the context of international commercial arbitration. ${ }^{106}$

In the case before the German Supreme Court, the claimant, a general partner in a limited partnership (Kommanditgesellschaft, KG), and the respondent signed a contract subject to KG's General Conditions of Contract. ${ }^{107}$ Clause no. 15 of these General Conditions stated:

"The outcome of the arbitration can be recognized by both parties as conclusive, final and binding on both parties. If one of the parties is dissatisfied with the outcome of the arbitration, it shall commence a court action within a month from the date of the arbitral decision. If this time limit expires, the arbitral decision shall be final and binding on both parties." 108

101 See Superior Court of Quebec of 15/2/2000, C.S.Qué. Montréal 500-05-043881-984, La Compagnie Nationale Air France v. Libyan Arab Airlines, [2000] R.J.Q. 717, para. 61; Superior Court of Quebec of 9/9/1994, C.S.Qué. Montréal 500-05-000806-941, International Civil Aviation Organization v. Tripal Systems Pty. Ltd., 1994 CarswellQue 912, p. 34.

102 See German Supreme Court of 1/3/2007, III ZB 7/06.

103 Section 1025(1) of the ZPO. The rules of the present Book are to be applied where the venue of the arbitration proceedings in the sense as defined by section 1043(1) is located in Germany.

104 Böckstiegel/Kröll/Nacimiento, Germany as a Place for International and Domestic Arbitrations - General Overview, in: Böckstiegel/Kröll/Nacimiento (eds.), Arbitration in Germany: The Model Law in Practice, 2007, p. 5, para. 4.

105 Deutscher Bundestag, Entwurf eines Gesetzes zur Neuregelung des Schiedsverfahrensrechts, BT-Drs. 13/5274 of 12/7/1996, p. 1.

106 See Wolff, (fn. 51), p. 631.

107 For more information about the facts of the case see van den Berg, Not indicated v. Not indicated, Bundesgerichtshof [Supreme Court], III ZB 07/06, 1 March 2007, in: van den Berg (ed.), Yearbook Commercial Arbitration, Vol. XXXIII, 2008, pp. 231-233 or visit: www.dis-arb.de/de/47/ datenbanken/rspr/bgh-az-iii-zb-07-06-datum-2007-03-01-id665 (1/10/2014).

108 Ibid., p. 231 et seq. (English translation). See German Supreme Court of 1/3/2007, III ZB 7/06, para. 2. 
Accordingly, if one of the parties were to commence court action, this would lead to a de novo review, i.e. révision au fond - a new procedure before the state courts where the law and facts are reviewed.

\section{a) De novo review: falling under the Model Law or not?}

The fact that the German Supreme Court was dealing with a de novo review and not a traditional review on merits has caused additional confusion, some authors expressing the view that these are different matters that should not be confused. ${ }^{109}$ While judicial review of an award is clearly a matter governed by the law, "one could doubt whether a de novo review after termination of the arbitral agreement (as construed by the German Federal Supreme Court) is also governed by the Model Law". ${ }^{110}$ Should a de novo review not fall under the scope of the Model Law, parties would not be limited by mandatory rules and would therefore be free to agree to such a review.

There is, admittedly, a difference between a de novo review and a review on merits. A de novo review is, as the wording indicates, a new procedure before a state court where the court examines the law and facts independently from the tribunal's prior decision with the right to substitute the tribunal's award with its own decision. A traditional review on the merits, on the other hand, is narrower. The court is usually only allowed to review questions of law, not questions of fact. Further, it has the power to review and decide only on petitions filed in the proceeding and cannot go beyond it. Obviously, a de novo review constitutes a more intrusive recourse compared to a traditional review on merits.

However, in order to see whether a de novo review falls under the scope of the Model Law, one has to determine whether such a review constitutes recourse against an award. This is due to the fact that the Model Law regulates all possible recourse against an award in state courts and limits them to the setting aside procedure. ${ }^{111}$ To answer this question, one first has to understand the terms and then decide whether there is an overlap between them. On the one hand, recourse against an award is any "means through which a party may actively 'attack' the award". ${ }^{112}$ By attacking the award, the party intends to "destroy" the award and deprive it of any effect. On the other hand, a de novo review is a new procedure before a state court where the court examines the law and facts independently. The

109 See Kröll, Die schiedsrechtliche Rechtsprechung 2007, SchiedsVZ 2008, p. 63. Kröll concurs with the decision but further states that a clause providing for a review of the merits of the award would be in conflict with the essential features of arbitration. See also Saenger, Zivilprozessordnung, 5th ed. 2013, § 1029, para. 12; Wolff, (fn. 51), p. 635; Kröll/Kraft, Part II - Commentary on the German Arbitration Law (10th Book of the German Code of Civil Procedure), Chapter VII - Recourse Against the Award, $§ 1059$ - Application for Setting Aside, in: Böckstiegel/Kröll/ Nacimiento, (fn. 104), p. 451, fn. 66.

110 Wolff, (fn. 51), p. 635.

111 See UNCITRAL Secretariat, (fn. 9), para. 44: “[...] Model Law, which provides uniform grounds upon which (and clear time periods within which) recourse against an arbitral award may be made." The same applies to the German arbitration law. Section 1059 of the ZPO is the single article of chapter 7 named "Rechtsbehelf gegen den Schiedsspruch" or "Legal remedies against the arbitral award".

112 UNCITRAL Secretariat, (fn. 9), para. 45. 
court has the possibility to reverse the award and substitute it with its own decision and in that case, the arbitral award will be deprived of its effect.

Due to the effects of a de novo review and recourse against an award generally being the same, it is correct to conclude that a de novo review constitutes recourse against an award and thus falls under the scope of the Model Law. The German Supreme Court decision cannot therefore be disregarded when elaborating on the possibility to contractually expand judicial review.

\section{b) Decision and reasoning}

The German Supreme Court found that Clause no. 15 of the applicable General Conditions, which provides for a de novo review, is an arbitration agreement in the sense of section 1029(1) of the $\mathrm{ZPO}^{113}$ and does not constitute a conciliation or mediation clause although the survival of the award is dependent on the parties and their discretion. ${ }^{14}$ The court based its reasoning on party autonomy forming the cornerstone of commercial arbitration. Parties' agreement to submit their dispute to arbitral proceedings is the basis of arbitration and it is this agreement that gives the binding effect to the award rendered by the tribunal. ${ }^{115}$ If the arbitration clause agreed upon by parties' forms the basis for the binding effect of the award, parties should also be permitted to impose conditions on that effect. For that reason, the court held that the parties could agree, which they indeed did, that their dispute be decided by an award but that the award would have no effect if proceedings on the matter were initiated before state courts within the set time limit of one month. This constituted a condition subsequent (auflösende Bedingung). ${ }^{116}$

The German Supreme Court further dismissed the possibility of raising serious procedural complaints in relation to such an agreement. ${ }^{117}$ Accordingly, section 1025 et seq. of the ZPO do not prohibit the parties from imposing a condition on the finality of the award. In particular, a complete exclusion of state courts' jurisdiction is not required by section 1029(1) of the ZPO.

Finally, the German Supreme Court put forth some practical points in favor of allowing awards with limited binding effect, for example the factual equality between regular awards and awards with limited binding effect. Once the time limit for commencement of state

113 Section 1029(1) of the ZPO states: "An arbitration agreement is an agreement by the parties that they subject themselves to the decision passed by an arbitral tribunal on all or individual disputes that have arisen between them or may arise in future as regards a specific legal relationship that is contractual or non-contractual in nature". Section 1029(1) of the ZPO mirrors the wording of Article 7(1) of the Model Law.

114 See German Supreme Court of 1/3/2007, III ZB 7/06, para. 15 et seq. (English translation in: van den Berg, (fn. 107), p. 234).

115 Accord Solomon, Die Verbindlichkeit von Schiedssprüchen in der internationalen privaten Schiedsgerichtsbarkeit, 2007, pp. 293, 299, 319-320.

116 See German Supreme Court of 1/3/2007, III ZB 7/06, para. 18 (English translation in: van den Berg, (fn. 107), p. 234 et seq.).

117 Ibid., para. 19. 
court action has expired, the award becomes final and binding. Such an award does not differ from a regular arbitral award. ${ }^{118}$

Thus, according to the German Supreme Court, parties can agree to a de novo review without violating the German arbitration law. Party autonomy allows the parties to condition the finality of an award in such a way that an award would be final and binding only if no proceedings in the same matter are initiated before state courts within the prescribed time period. ${ }^{119}$

\section{c) Criticism of the decision}

The German ruling admittedly contradicts the prevailing opinion that an expanded judicial review is not permissible and has therefore unsurprisingly caused some controversy. Some have taken a rather neutral position, welcoming the endorsement of party autonomy on the one hand, but expressing concerns on the other. ${ }^{120}$ However, there is a split in the legal community between the supporters ${ }^{121}$ and opponents ${ }^{122}$ of the German Supreme Court's ruling.

Wolff criticized the decision as both legally erroneous and unreasonable, thereby giving priority to the finality of award. He deems arbitration an alternative to state litigation and allowing a re-evaluation of the correctness of the tribunal's award would run counter to the nature and basic characteristics of arbitration, namely that unlike a state court, a tribunal renders a decision, which is binding and final, and that the tribunal does not constitute a mere first step whose award is reviewed on the merits by state courts. ${ }^{123}$ In support of this position, Wolff makes use of the wording of Article 5 of the Model Law, ${ }^{124}$ which in his view not only restricts court intervention to what is provided in the law itself but "also disallows parties to agree on a wider scope of court intervention". ${ }^{125}$ Moreover, it would be unreasonable to allow state courts to review on merits, as it would undermine the advantages of arbitration, for example the influence on the choice of people resolving the dispute, flexibility, confidentiality, cost and time efficiency. ${ }^{126}$ In addition, the international community prefers finality of awards, which overweighs the need for an appeal procedure. ${ }^{127}$

118 Ibid., para. 20.

119 See Böckstiegel/Kröll/Nacimiento, (fn. 104), p. 51, para. 131.

120 See Elsing, Anmerkung zu der BGH Entscheidung, JR 2008, p. 243.

121 See Saenger, (fn. 109), § 1029, para. 12; Kröll, (fn. 109), p. 63. Yet, Kröll is of the opinion that a qualification as a condition precedent would be more appropriate. For more information on this issue see Wietzorek, Chapter III: The Award and the Courts, Agreements on an Expanded Judicial Review of Arbitral Awards, in: Klausegger/Klein et al. (eds.), Austrian Yearbook on International Arbitration, 2014, pp. 359-361; Solomon, (fn. 115), pp. 364-366.

122 See Wolff, (fn. 51).

123 See Kröll, (fn. 109), p. 63; Wolff, (fn. 51), p. 633.

124 The same wording is adopted in section 1026 of the ZPO.

125 Wolff, (fn. 51), p. 635.

126 See ibid., p. 639.

127 See ibid., p. 638 et seq. 
Granted, these concerns are valid, but basing a decision purely hereon would be taking an unduly restrictive view of matters - one would, in a sense, be only looking at one side of the coin. Prohibiting expanded judicial review on the ground that arbitration is meant to be an alternative to state court proceedings would be going too far, for it would result in the exclusion of all court involvement in the post-award stage, even for major procedural deficiencies and public policy considerations. ${ }^{128}$ Moreover, arbitration, although substituting state court proceedings, is primarily a private system for dispute resolution chosen and controlled by the parties, the latter having the ultimate power to tailor arbitration in a way that suits them best. ${ }^{129}$ As a result, considerations by the international community ought to be disregarded and the emphasis placed on the wishes of the parties to arbitration. If the parties want to give up some of the advantages of arbitration, they should be free to do so. In fact, the law itself grants parties such a possibility, for instance in relation to the appointment of arbitrators. ${ }^{130}$ Furthermore and as previously stated, a review on merits cannot be deemed antithetical to the principle of finality, ${ }^{131}$ because the latter would imply the exclusion of any possible recourse against an award. ${ }^{132}$ German arbitration law, by providing for a setting aside procedure in section 1059 of the ZPO, places a condition on finality itself. Moreover, an appeal of an award to a second instance of the tribunal is undoubtedly admitted if the parties agree hereto. ${ }^{133}$ Parties have full freedom to decide on the composition of the second appellate panel and should they opt for completely new arbitrators, the work of such a panel would not differ from the work of a court reviewing the merits. For these reasons, the argument on finality of the award cannot stand.

As party autonomy forms the basis of arbitration, parties should be free to tailor the latter to their needs, subject to mandatory provisions of the law. For the sake of convenience, this paper will refrain from repeating the legal argumentation on the (non-)mandatory nature of Article 34 of the Model Law ${ }^{134}$ (which matches section 1059 of the ZPO) ${ }^{135}$ and will reiterate that, by taking the proper subjective method of interpretation, parties are free to

128 See Paulsson, The idea of Arbitration, 2013, p. 98.

129 See Schmitthof, Finality of arbitral awards and judicial review, in: Lew (ed.), Contemporary Problems in International Arbitration, 1986, p. 230; Lew/Mistelis/Kröll, (fn. 3), p. 3, para. 1-10 et seq.

130 One of the advantages of arbitration is that the parties have the possibility of influencing arbitral proceedings through the appointment of arbitrators. According to Article 11 of the Model Law (section 1035 of the ZPO) the parties are free to agree on the procedure of appointment, but if parties fail to agree on it and/or fail to appoint the arbitrators according to the prescribed procedure, the competent court will make the appointment. By acting in that way, parties are giving up this advantage of arbitration.

131 See D.I.2.

132 See Kröll/Kraft, (fn. 109), p. 437.

133 See fn. 94. See also Wolff, (fn. 51), p. 640.

134 See D.I.2.

135 Section 1059(1)-(3) of the ZPO is largely a verbatim adoption of Article 34 of the Model Law. See Kröll/Kraft, (fn. 109), p. 238: "Differences exist in relation to the shortened time-limits in cases where an application for correction or interpretation has been made and in relation to the absence of the possibility to stay the setting aside proceedings to allow the arbitral tribunal to remedy the alleged defects. Instead, § 1059(4) ZPO explicitly foresees the remittance of the case to the arbitral tribunal after the award has been set aside. In addition, § 1059(5) ZPO has no equivalent in the [Model Law]". 
agree on expanded judicial review. Thus, the German Supreme Court rightly held that there is no provision prohibiting parties to condition the finality of an award and that parties are free to agree on a de novo review. In light of parties being allowed to contract for a de novo review, parties' agreement to subject the award to a review on the merits - a recourse undoubtedly less intrusive then a de novo review - should argumentum a fortiori be deemed valid.

\section{Conclusion}

As previously illustrated, the provisions of the Model Law neither explicitly qualify Article 34 as mandatory nor clearly prohibit parties from expanding judicial review. Hence, the validity of parties' agreement expanding judicial review will depend on the competent court and its interpretation of the law.

The German Supreme Court's decision poses somewhat of an exception in Model Law jurisdictions. It broke away from traditional rulings prohibiting expanded judicial review and made the arbitration community rethink the concept of arbitration. The Model Law restricted court involvement and provided one single means of recourse against an award in order to protect parties from unwanted and unexpected court involvement. But in cases where sophisticated commercial parties expressly agree to a broader standard of review, there is no need for protection and hence there is no ground for courts to preclude parties from getting what they consensually bargained for.

\section{E. Judicial review and parties' right of expansion under the U.S. Federal Arbitration Act}

When analysing expanded judicial review, one must inevitably address the situation under the U.S. Federal Arbitration Act (FAA) due to numerous U.S. court rulings on the issue, which have attracted the attention of the international arbitral community. The FAA was enacted on 12 February 1925 and is codified in Title 9 of the United States Code. It constitutes the federal arbitration law in the United States for international as well as domestic arbitration and is divided in three chapters. ${ }^{136}$ Chapter I sets out the governing law for domestic arbitration, while chapters II and III can be defined as the "international chapters" giving effect to the New York Convention and the Panama Convention. ${ }^{137}$ Chapters II and III, however, do not incorporate verbatim the Conventions, as it is usual practice, but include additional provision for the application of these Conventions in the U.S. ${ }^{138}$

Although there are different chapters dealing with domestic and international arbitration, there is no strict boundary between them. ${ }^{139}$ Chapter I has residual application with regard

136 See Roth, (fn. 62), p. 877, para. 13.02.

137 See Strong, International Commercial Arbitration: A Guide for U.S. Judges, Federal Judicial Center, 2012, p. 24.

138 See ibid.

139 See Roth, (fn. 62), p. 880, para. 13.11. 
to both chapters II and III, which is explicitly stated in the latter. ${ }^{140}$ Chapter I applies to international arbitration to the extent that its provisions do not conflict with the provisions of the next two chapters. Due to this interconnection between the law governing international arbitration and that governing domestic arbitration, it is advisable to give due regard to precedents set in domestic arbitration, as they may construe legal principles which can subsequently be transposed and applied in the international context. ${ }^{141}$

An international award falling under the New York Convention and hence chapter $\mathrm{II}^{142}$ shall be confirmed by the court

"unless it finds one of the grounds for refusal or deferral of recognition or enforcement of the award specified in the [New York] Convention". ${ }^{143}$

The U.S. courts are divided on whether the standard of the New York Convention or the FAA should be used to vacate an international award. ${ }^{144}$ Some have held that only the grounds in Article V of the New York Convention can be invoked in actions to vacate an international award rendered in the United States. ${ }^{145}$ Others, however, have found that the vacatur of international awards follows on the grounds for the vacatur of domestic awards, as set out in section 10 of the FAA, because parties to an arbitration seated in the U.S. subject themselves to the domestic regime for vacating awards. ${ }^{146}$ This follows from the text of the New York Convention, whose Article V(1)(e) stipulates that the recognition and enforcement of an award may be refused if the award

140 See section 208 and section 307 of the FAA. See also Strong, (fn. 137), p. 25; Roth, (fn. 62), p. 880 , para. 13.11 .

141 See ibid., p. 880, para. 13.12 .

142 Chapter II applies to awards rendered in arbitral proceedings between a U.S. party and a foreign party, between foreign parties solely and between U.S. citizens under the condition that there is some international element in their relation. Arbitral proceedings that involve only U.S. citizens and do not contain any international element are subject to domestic arbitration rules in chapter I. See section 1 of the FAA in connection with section 202 of the FAA. See also Strong, (fn. 137), p. 26.

143 Section 207 of the FAA.

144 See Strong, (fn. 137), p. 65.

145 See e.g., U.S. Court of Appeals, Eleventh Circuit of 22/5/1998, Nos. 94-2982,94-2530, Industrial Risk Insurers v. M.A.N. Gutehoffnungshütte GmbH, 141 F.3d 1434, p. 1441: “[...] arbitral award must be confirmed unless appellants can successfully assert one of the seven defenses against enforcement of the award enumerated in Article V of the New York Convention". See also Strong, (fn. 137), p. 65 et seq.

146 See e.g., U.S. Court of Appeals, Second Circuit of 10/9/1997, No. 1757, Docket 96-9692, Yusuf Ahmed Alghanim \& Sons, W.L.L. v. Toys “R”'Us, Inc.; TRU (HK) Limited, 126 F.3d 15, p. 19: "Toys" $R$ "Us argues that the district court properly found that it had the authority under the Convention to apply the FAA's implied grounds for setting aside the award. We agree". See also Strong, (fn. 137), p. 66; Tyler/Parasharami, Finality over Choice: Hall Street Associates, L.L.C v. Mattel, Inc. (U.S. Supreme Court), Journal of International Arbitration 25 (2008), p. 614. 
"[...] has been set aside or suspended by a competent authority of the country in which, or under the law of which, that award was made". ${ }^{147}$

The provision was read as allowing the court at the seat of arbitration to apply domestic arbitration law when dealing with an application to vacate an arbitral award. ${ }^{148}$ Due to the lack of a clear judicial stance on the matter, it is important to consider relevant court rulings rendered in domestic arbitration when elaborating on the possibility of contractually expanded judicial review in international arbitration under the FAA.

\section{Vacating arbitral awards under section 10 of the FAA}

Recourse against domestic awards rendered in the U.S. is regulated by section 10 of the FAA, which allows for motions to vacate awards. It provides that "the United States court in and for the district wherein the award was made may make an order vacating the award upon the application of any party to the arbitration" if the grounds listed are met, namely:

(1) where the award was procured by corruption, fraud, or undue means;

(2) where there was evident partiality or corruption in the arbitrators, or either of them;

(3) where the arbitrators were guilty of misconduct in refusing to postpone the hearing, upon sufficient cause shown, or in refusing to hear evidence pertinent and material to the controversy; or of any other misbehavior by which the rights of any party have been prejudiced; or

(4) where the arbitrators exceeded their powers, or so imperfectly executed them that a mutual, final, and definite award upon the subject matter submitted was not made.

\section{Judgments prior to the U.S. Supreme Court's ruling in "Hall Street v. Mattel"}

American courts have frequently dealt with cases where parties have contractually expanded judicial review. However, the courts have not taken a unanimous position when resolving the admissibility of such an extension. Prior to the Supreme Court's decision in Hall Street v. Mattel in 2008, ${ }^{149}$ American courts were divided on the issue of expanded

147 See U.S. Court of Appeals, Second Circuit of 10/9/1997, No. 1757, Docket 96-9692, Yusuf Ahmed Alghanim \& Sons, W.L.L. v. Toys “R”Us, Inc.; TRU (HK) Limited, 126 F.3d 15, p. 19 et seq.

148 See ibid., pp. 21-23.

149 U.S. Supreme Court of 25/3/2008, No. 06-989, Hall Street Associates L.L.C. v. Mattel Inc., 552 U.S. 576. 
judicial review, some allowing it, ${ }^{150}$ others prohibiting it. ${ }^{151}$ While it seems the situation had changed and the rift between the courts was brought to an end in 2008, controversies still remain. ${ }^{152}$

\section{The U.S. Supreme Court's judgment in "Hall Street v. Mattel"}

The Supreme Court of the United States attempted to end this difference of opinion in 2008 with its decision in Hall Street v. Mattel. ${ }^{153}$ In that case, the parties had bargained and agreed on an arbitration agreement which provided that

"[t]he United States District Court for the District of Oregon may enter judgment upon any award, either by confirming the award or by vacating, modifying or correcting the award. The Court shall vacate, modify or correct any award: (i) where the arbitrator's findings of facts are not supported by substantial evidence, or (ii) where the arbitrator's conclusions of law are erroneous." 154

The Supreme Court held, with a six to three majority, that the grounds for vacatur and modification of arbitral awards are exclusively confined to those contained in section 10 and 11 of the FAA and that parties cannot therefore contract to go beyond the statutory grounds.

150 U.S. Court of Appeals, Ninth Circuit of 9/12/1997, Nos. 96-15319, 96-15321, 96-16142, 96-16143, 96-16318, LaPine Technology Corporation v. Kyocera Corporation, 130 F.3d 884, p. 889; U.S. Court of Appeals, Fifth Circuit of 27/9/1995, Nos. 93-1101,94-10787, Gateway Technologies, Inc. v. MCI Telecommunications Corp., 64 F.3d 993, p. 997; U.S. District Court, S.D. New York of 5/4/1984, No. 83 Civ. 7073 (WCC), Fils et Cables d'Acier de Lens v. Midland Metals Corporation, 584 F.Supp. 240, p. 244; U.S. Court of Appeals, First Circuit of 14/10/2005, Nos. 04-2601,04-2602, Puerto Rico Telephone Company, Inc. v. U.S. Phone Manufacturing Corporation, 427 F.3d 21, p. 23; U.S. Court of Appeals, Fourth Circuit of 11/8/1997, No. 96-2261, Syncor Int'l Corporation v. David L. McLeland, 120 F.3d 262, p. 6. See also Moses, (fn. 42), pp. 429-465; Murray, Contractual Expansion of the Scope of Judicial Review of Arbitration Awards Under the Federal Arbitration Act, St. John's L. Rev. 76 (2002), pp. 633-645; Cullinan, Contracting for an expanded judicial review in arbitration agreements, Vand. L. Rev. 51 (1998), pp. 400-408; Van Ginkel, Reframing the Dilemma of Contractually Expanded Judicial Review: Arbitral Appeal vs. Vacatur, Pepp. Disp. Resol.L.J. 3 (2003), pp. 167-178.

151 U.S. Court of Appeals, Ninth Circuit of 29/8/2003, Nos. 01-15630, 01-15653, 01-16182, 01-16394, 01-16528, Kyocera Corporation v. Prudential-Bache Trade Services, 341 F.3d 987, p. 1000; U.S. Court of Appeals, Tenth Circuit of 20/6/2001, No. 00-7039, Bowen v. Amoco Pipeline Company, 254 F.3d 925, p. 937; U.S. Court of Appeals, Seventh Circuit of 25/6/1991, Nos. 90-3501,90-3503, Chicago Typographical Union No. 16 v. Chicago Sun-Times, Incorporated, 935 F.2d 1501, p. 1505. See also Van Ginkel, (fn. 150), pp. 162-167; Moses, (fn. 42), pp. 429-465; Murray, (fn. 150), pp. 633-645; Cullinan, (fn. 150), pp. 400-408.

152 See e.g., Drahozal, Contracting Around Hall Street, Lewis \& Clark L. Rev. 14 (2010), p. 905 et seqq. or Mitzner, Snatching Arbitral Freedom from Hall Street's Clenched Fist, Rev. Litig. 29 (2009), p. 179 et seqq.

153 U.S. Supreme Court of 25/3/2008, No. 06-989, Hall Street Associates L.L.C. v. Mattel Inc., 552 U.S. 576.

154 Ibid., p. 579. 
Accordingly, expanding the statutory grounds would contravene the wording of section 9 of the FAA, which states that after a party has applied to the court for an order confirming the award,

"the court must grant such an order unless the award is vacated, modified, or corrected as prescribed in sections 10 and $11[\ldots] . "$

The words "must grant" provide the court with no flexibility or discretion, and the court has to grant confirmation unless it concludes that one of the enumerated grounds is present. The Supreme Court explained that section 9 is not a default provision instructing courts what to do in the event that parties do not regulate the matter themselves, ${ }^{155}$ and gave section 5 of the FAA as an example of what Congress intended as a default provision. ${ }^{156}$ Rather, sections 9-11 of the FAA affirm the

"national policy favoring arbitration with just the limited review needed to maintain arbitration's essential virtue of resolving disputes straightaway". ${ }^{157}$

Despite providing what at first glance might seem like a clear position, the Supreme Court did not completely exclude the possibility of expanding judicial review. Accordingly, the parties are not precluded from seeking "more searching review based on authority outside the statute". ${ }^{158}$ The Supreme Court further adduced that

"the FAA is not the only way into court for parties wanting review of arbitration awards: they may contemplate enforcement under state statutory or common law, for example, where judicial review of different scope is arguable." 159

The judgment has elicited criticism from the dissenting judges as well as academics. ${ }^{160}$ Justice Stevens, with whom Justice Kennedy concurred, felt that forbidding the enforcement of a perfectly reasonable review provision would contradict the FAA's historical context and its primary purpose of

155 Ibid., p. 587 et seq.

156 Ibid. Section 5 of the FAA states: "If in the agreement provision be made for a method of naming or appointing an arbitrator or arbitrators or an umpire, such method shall be followed; but if no method be provided therein, $[. .$.$] the court shall designate and appoint an arbitrator or arbitrators$ or umpire [...]."

157 U.S. Supreme Court of 25/3/2008, No. 06-989, Hall Street Associates, L.L.C. v. Mattel, Inc., 552 U.S. 576, p. 588.

158 Ibid., p. 590.

159 Ibid.

160 See e.g., Rau, Fear of Freedom, Am. Rev. Int'l. Arb. 17 (2006), p. 482: "What truly appalled me about Hall Street, however, is not so much the unfortunate result, but rather the grotesque deficiencies in craftsmanship, in rhetoric, in argument. What we have, to be precise, is a remarkably inept and amateurish performance: A hapless law student would merit a $\mathrm{C}$ for this [...]". Born, (fn. 1), p. 3376; Mitzner, (fn. 152), pp. 180-190; Ginsburg, The Arbitrator as Agent: Why Deferential Review is Not Always Pro-Arbitration, U. Chi. L. Rev. 77 (2010), p. 1023 et seq.; Barcelo III, (fn. 41), p. 6. 
"ensur[ing] that private arbitration agreements are enforced according to their terms" ${ }^{161}$

This interest in respecting parties' agreement is stronger today than at the time of the enactment of the Act and thus, "there is more - and certainly not less - reason"162 to enforce parties' agreement to expand judicial review. Prior to the enactment of the FAA courts were generally hostile towards arbitration ${ }^{163}$ and consequently parties' agreements were frequently infringed. So as to restrict unwanted court intervention in the post-award stage, sections 10 and 11 of the FAA were enacted and these provisions are best understood as

" $[\ldots]$ a shield meant to protect parties from hostile courts, not a sword with which to cut down parties' 'valid, irrevocable and enforceable' agreements to arbitrate their disputes subject to judicial review for errors of law". 164

Unfortunately, the only pertinent question asked by Justice Stevens in the oral hearing, namely " $[w]$ hy do [the courts] want to prevent the parties from choosing the option they chose in this case?", ${ }^{165}$ was not answered.

Besides neglecting the purpose and historical context of the FAA, the Supreme Court erred when stating that sections 9 and 10 of the FAA are mandatory provisions. As highlighted by a commentator, these provisions "are 'inflexible' only because the Court so declared". ${ }^{166}$ The Supreme Court supported its decision with a comparison between the wording of sections 5 and 9 of the FAA. ${ }^{167}$ If one were to follow the Supreme Court's strict interpretation of the wording of these two provisions and apply it to other provision of the FAA, such as section 3 , one would arrive at erroneous conclusions. ${ }^{168}$ Section 3 of the FAA regulates the stay of court proceedings where the issue is referable to arbitration and stipulates that

"the court in which the suit is pending, upon being satisfied that the issue involved [...] is referable to arbitration under such an agreement, shall on application of one of the parties stay the trial $[\ldots]$ ".

Applying the Supreme Court's interpretation would lead to the conclusion that the court has the exclusive jurisdiction to decide whether a particular dispute is covered by the ar-

161 U.S. Supreme Court of 6/3/1989, No. 87-1318, Volt Information Sciences, Inc. v. Board of Trustees of Leland Stanford Junior University, 489 U.S. 468, p. 478. Accord Dissenting Opinion of Justice Stevens in U.S. Supreme Court of 25/3/2008, No. 06-989, Hall Street Associates, L.L.C. v. Mattel, Inc., 552 U.S. 576, p. 593.

162 Ibid.

163 See Born, (fn. 1), pp. 40-45.

164 Dissenting Opinion of Justice Stevens in U.S. Supreme Court of 25/3/2008, No. 06-989, Hall Street Associates, L.L.C. v. Mattel, Inc., 552 U.S. 576, p. 594. Accord Justice Breyer in his dissent in ibid., p. 596.

165 Rau, (fn. 160), p. 487.

166 Born, (fn. 1), p. 3376.

167 U.S. Supreme Court of 25/3/2008, No. 06-989, Hall Street Associates, L.L.C. v. Mattel, Inc., 552 U.S. 576, p. 588: “'[I]f no method be provided' is a far cry from 'must grant [...] unless' in $\S 9$ ".

168 Section 3 of the FAA states: "If any suit or proceeding be brought in any of the courts of the United States $[\ldots]$ the court in which such suit is pending, upon being satisfied that the issue involved in such suit or proceeding is referable to arbitration under such an agreement, shall on application of one of the parties stay the trial of the action [...]". See Rau, (fn. 60), p. 492. 
bitration agreement, irrespective of what the parties agreed to. ${ }^{169}$ Such a conclusion would be wrong, as indicated by the Supreme Court in First Options of Chicago, Inc. v. Kaplan. ${ }^{170}$ Hence, the default distribution of powers between a court and the tribunal does not imply parties' power to tailor the arbitration as it suits them best. ${ }^{171}$ Therefore, once viewed in light of the primary purpose of enforcing parties' intent as demonstrated in the arbitration agreement, section 10 of the FAA has to be understood as a list of grounds that in any case must be available to the parties but which does not preclude parties from agreeing on additional grounds of judicial review. ${ }^{172}$

A limitation of party autonomy could arise on grounds of public policy, but if there is a public policy in arbitration, it does not consist in settling the dispute in the quickest possible manner but in making an efficient dispute resolution process available to the parties, which would finally be subjected to parties' agreement. ${ }^{173}$ The Supreme Court has reminded the arbitral community in several cases that the primary purpose of the FAA was to "ensure judicial enforcement of privately made agreements to arbitrate" and not to "promote the expeditious resolution of claims". ${ }^{174}$ An expeditious and efficient resolution of disputes may be an advantage of arbitration that attracts parties to choose this method of settlement, but it is not arbitration's fundamental purpose itself. Arbitration is above all a contractual method of dispute resolution founded on parties' freedom to contract. ${ }^{175}$ Parties, by agreeing on expanded judicial review, evidently sacrifice and trade speed and finality of an award for a wider judicial review. Disallowing parties this possibility in order to protect the process and its finality would in fact destroy arbitration as agreed by the parties and run counter to the purpose of the FAA. ${ }^{176}$

The goal of federal courts, as faithful agents of Congress, should be to ascertain and follow its commands. ${ }^{177}$ Normally, the intention of the drafter can be found in the wording

169 See ibid.

170 U.S. Supreme Court of 22/5/1995, No. 94-560, First Options of Chicago, Inc. v. Kaplan, 514 U.S. 938, p. 943: "Just as the arbitrability of the merits of a dispute depends upon whether the parties agreed to arbitrate that dispute [...] so the question "who has the primary power to decide arbitrability' turns upon what the parties agreed about that matter". Accord Rau, (fn. 160), p. 493 , fn. 68 .

171 See ibid., p. 492 et seq.

172 Dissenting Opinion of Justice Stevens in U.S. Supreme Court of 25/3/2008, No. 06-989, Hall Street Associates, L.L.C. v. Mattel, Inc., 552 U.S. 576, p. 594 et seq.

173 Rau, (fn. 160), p. 479.

174 U.S. Supreme Court of 4/3/1985, No. 83-1708, Dean Witter Reynolds, Inc. v. Byrd, 470 U.S. 213, p. 219. Accord U.S. Supreme Court of 22/5/1995, No. 94-560, First Options of Chicago, Inc. v. Kaplan, 514 U.S. 938, p. 947: "[...] the basic objective in this area is not to resolve disputes in the quickest manner possible, no matter what the parties' wishes, [...], but to ensure that commercial arbitration agreements, like other contracts, "are enforced according to their terms', [...], and according to the intentions of the parties, [...]." U.S. Supreme Court of 6/3/1989, No. 87-1318, Volt Information Sciences, Inc. v. Board of Trustees of Leland Stanford Junior University, 489 U.S. 468, p. 478. See also Rau, (fn. 160), p. 479.

175 See Mitzner, (fn. 152), p. 189 et seq.

176 See Fernandez, Be Quick - but Don't Hurry: Competing Purposes of the Federal Arbitration Act and Hall Street Associates v. Mattel, La. L. Rev. 70 (2009), pp. 402-406.

177 See Manning, What Divides Textualists from Purposivists?, Colum. L. Rev. 106 (2006), p. 71. 
of the provision, but this is not always the case. ${ }^{178}$ Thus, courts should not only look at the plain meaning of the provision, but should also take into account the context, because the real meaning will in some cases depend on the purpose of enacting the legislation in question. ${ }^{179}$ In Hall Street, the Supreme Court failed to take a holistic approach to the FAA, sticking instead only to its wording. Such an approach is at variance with basic principles of interpretation, which demand consideration of a measure's objective and purpose.

\section{Judgments in the aftermath of "Hall Street"}

Since a number of questions addressed by the Supreme Court remained unanswered, like the "manifest disregard of the law" doctrine, ${ }^{180}$ one has to agree with Justice Breyer who identified Hall Street as

"the case of the century, because it's going to take a hundred years to finish". ${ }^{181}$

But irrespective of one's empathy with the finding of the Supreme Court, the decision is seemingly clear: the statutory grounds for vacating the award are exclusive and parties cannot modify or add any other ground. Consequently, one would expect courts in subsequent cases to comply with the standard set out by the Supreme Court in Hall Street and not permit a review on merits. Nevertheless, courts have found ways to circumvent the ruling of Hall Street and make it easier to vacate arbitral awards.

Several states' supreme courts limited the impact of the Hall Street decision by finding expanded judicial review valid under their state laws. ${ }^{182}$ The highest state courts in California and Texas have held that judicial review on the merits is permissive under their state

178 See U.S. Supreme Court of 26/10/1897, No. 35, United States v. Goldenberg, 168 U.S. 95, p. 102 et seq. See also Manning, Textualism and the Equity of the Statute, Colum. L. Rev. 101 (2001), p. 104.

179 See U.S. Supreme Court of 6/12/1995, Nos. 94-7448, 94-7492, Bailey v. United States, 516 U.S. 137, p. 146, where the court denied to give the usual meaning to the word and took into account the intention of the Congress: "We disagree. Nothing here indicates that Congress, when it provided these two terms, intended that they be understood to be redundant". See also Eskridge, All About Words: Early Understandings of the "Judicial Power" in Statutory Interpretation, 1776-1806, Colum. L. Rev. 101 (2001), p. 1099.

180 See U.S. Supreme Court of 25/3/2008, No. 06-989, Hall Street Associates, L.L.C. v. Mattel, Inc., 552 U.S. 576, p. 585: "Maybe the term 'manifest disregard' was meant to name a new ground for review, but maybe it merely referred to the $\S 10$ grounds collectively, rather than adding to them."

181 U.S. Supreme Court of 7/11/2007, Transcript of the Oral Hearing in Hall Street v. Mattel, www.supremecourt.gov/oral_arguments/argument_transcripts.aspx (1/10/2014), p. 40, lines 6-8. See also Wolff, (fn. 51), p. 639.

182 E.g., Supreme Court of California of 25/8/2008, No. S147767, Cable Connection, Inc. v. Directv, Inc., 44 Cal. 4th 1334; Supreme Court of Texas of 13/5/2011, No. 08-0613, Nafta Traders Inc. v. A. Quinn, 339 S.W.3d 84. Following the decision in Cable Connection Inc v. Directv Inc., expanded judicial review was granted in two other U.S. states. See Supreme Court of Alabama of 18/6/2010, 1081688, Raymond James Financial Services Inc v. Honea, 55 So.3d 1161; Superior Court of Connecticut of 2/8/2010, No. X08CV044002173S, East Greyrock L.L.C. v. OBC Associates Inc., 2010 WL 3448075 (Conn.Super.). Accord Griffith, Contractual Expansion of Judicial Review of Arbitration Awards in Missouri after Hall Street and Cable Connection, St. Louis U.L.J. 58 (2013), p. 265 et seqq. 
law when parties, in their arbitration agreement, limit arbitrators' power to make errors in their findings and defined such errors as arbitrators' excess of powers. In such situations the courts would simply perform a review on merits on the ground that arbitrators exceeded their power (section 1286.2(a)(4) of the California Code of Civil Procedure and section 171.088(a)(3)(A) of the Texas Civil Practice and Remedies Code). ${ }^{183}$ It is important to note that Californian arbitration law is highly similar to the FAA and contains almost identical provisions for vacating an award. ${ }^{184}$ The same holds true for Texas arbitration law. ${ }^{185}$

The Supreme Courts of California and Texas firmly stated that Hall Street is restricted to proceedings under the FAA and hence it does not preempt state law allowing parties to expand judicial review. ${ }^{186}$ Bar some minor differences, the reasoning provided by the Californian and Texas Supreme Court are largely similar. Both courts base their reasoning on arbitration's overriding goal of enforcing arbitration agreements according to its terms and the expectations of the parties. ${ }^{187}$ The parties may agree that arbitrators, who derive their power from the arbitration agreement, are not allowed to make any mistake in their finding and that should they do so, they be acting in excess of their powers. In such a situation, the parties will not expect to obtain a final and binding award after the proceedings close, but rather that the award will be subject to review by courts if one of the parties is of the opinion that such a mistake was made. Hence, parties should be granted the possibility of having a review on merits, which is possible on the ground that the arbitrators exceeded their powers. ${ }^{188}$

The Californian and Texas Supreme Court decisions are not the only examples of courts providing for a review on merits on the ground that arbitrators exceeded their powers. Most surprising, however, is that the Supreme Court of the United States also took this approach.

In Stolt-Nielsen v AnimalFeed ${ }^{189}$ the charterers, AnimalFeeds, commenced arbitral proceedings against the shipping companies, Stolt-Nielsen, alleging that they violated antitrust law by engaging in illegal price-fixing and demanding class arbitration. The arbitration

183 See Cable Connection, Inc. v. Directv, Inc., (fn. 182), p. 1361 and 1364; Nafta Traders Inc. v. A. Quinn, (fn. 182), p. 97.

184 The California arbitration law and the FAA are highly similar due to their shared origin in the earlier New Jersey and New York statute. Accord Cable Connection, Inc. v. Directv, Inc., (fn. 182), p. 1343. See also Feldman, Arbitration Law in California: Private Tribunals for Private Government, S. Cal. L. Rev. 30 (1956-1957), p. 388, fn. 45; Barcelo III, (fn. 41), p. 10.

185 See Clark, Getting Out of the Award: How Nafta Traders v. Quinn Affects the Grounds for Vacating an Award in Texas, Baylor L. Rev. 65 (2013), p. 615 et seq.; Grubbs/Blount/Post, Arbitration Agreements, Expanded Judicial Review, and Preemption - Hall Street Associates and Nafta Traders, Inc. - A National Debate with International Implications, Southern Law Journal 24 (2014), p. 11 et seq.

186 See Cable Connection, Inc. v. Directv, Inc., (fn. 182), p. 1354; Nafta Traders Inc. v. A. Quinn, (fn. 182), p. 101.

187 See Cable Connection, Inc. v. Directv, Inc., (fn. 182), p. 1353; Nafta Traders Inc. v. A. Quinn, (fn. 182), p. 90.

188 See Cable Connection, Inc. v. Directv, Inc., (fn. 182), p. 1355 et seq.; Nafta Traders Inc. v. A. Quinn, (fn. 182), p. 91.

189 U.S. Supreme Court of 27/4/2010, No. 08-1198, Stolt-Nielsen S.A. v. Animalfeeds International Corp., 559 U.S. 662. 
agreements in the international maritime contracts ${ }^{190}$ between the parties were silent as to the question of class arbitration and hence the parties entered into a supplemental agreement, which defined the rules for the tribunal in making a decision. ${ }^{191}$ Although the arbitrators concluded that the arbitration clause permits class arbitration, the District Court vacated the award on the ground that the award has been made in manifest disregard of the law. Accordingly, the arbitrators "manifestly disregarded a well-defined rule of governing maritime law that precluded class arbitration". ${ }^{192}$ The Court of Appeals of the Second Circuit reversed the District Court's finding. Although the Court of Appeals held that the "manifest disregard of the law" doctrine survived the Hall Street decision as a "judicial gloss" on the statutory grounds for vacatur, it proclaimed that the standard is very narrow and the award was not in manifest disregard of the law. ${ }^{193}$

The Supreme Court, whose conservative majority takes a somewhat sceptic view of class arbitration, did not favor the decisions of the arbitral tribunal and of the Court of Appeals. ${ }^{194}$ Hence, it was confronted with a difficulty; namely, on what ground to overturn the decision of the Court of Appeals without interfering with the Hall Street decision and employing the "manifest disregard of the law" doctrine. ${ }^{195}$

The Supreme Court started off by stating that in order to obtain a vacatur of the award,

"[i]t is not enough [...] to show that the panel committed an error - or even a serious error". ${ }^{196}$

Nonetheless, the Supreme Court established that:

"It is only when [an] arbitrator strays from interpretation and application of the agreement and effectively 'dispense[s] his own brand of industrial justice' that his decision may be unenforceable." 197

190 Section 1 of the FAA makes a distinction between maritime transaction subject to admiralty jurisdiction and other types of commerce. Yet, maritime transactions are considered commerce and hence disputes arising out of such transaction can be resolved by arbitration under the FAA.

191 According to this agreement, the tribunal will be bound by rules 3 through 7 of the American Arbitration Association's Supplementary Rules for Class Arbitrations when deciding the question of class arbitration. Rule 3 requires an arbitrator to decide, as a threshold matter, whether the arbitration can proceed as class arbitration under the arbitration clause.

192 U.S. District Court, S.D. New York of 26/6/2006, Stolt-Nielsen S.A. v. Animalfeeds International Corp., 435 F. Supp.2d 382, p. 386.

193 See U.S. Court of Appeals, Second Circuit of 4/11/2008, No. 06-3474-cv, Stolt-Nielsen S.A. v. Animalfeeds International Corp., 548 F.3d 85, pp. 94 and 96.

194 See Moses, Did the U.S. Supreme Court, in its Stolt-Niesen Decision, Make it Easier for Courts to Vacate Arbitration Awards?, Kluwer Arbitration Blog of 14/12/2010. See also Park, The Politics of Class Arbitration: Jurisdictional Legitimacy and Vindication of Contract Rights, Am. U. Int'l L. Rev. 27 (2012), p. 840 et seq.

195 See Moses, (fn. 194).

196 See U.S. Supreme Court of 27/4/2010, No. 08-1198, Stolt-Nielsen S.A. v. Animalfeeds International Corp., 559 U.S. 662, p. 671.

197 Ibid. 
The Supreme Court availed itself of the standard from a labor arbitration case ${ }^{198}$ and applied it to commercial arbitration by stating that if the described situation occurs, an arbitral award may be vacated under section 10(a)(4) of the FAA on the ground that the arbitrators exceeded their powers. The Supreme Court went on to express that arbitration "is a matter of consent, not coercion"199 and that an arbitrator's task is to interpret and enforce a contract and not to impose its own view of public policy, as the arbitrator did in the current case. ${ }^{200}$

The Supreme Court engaged itself in a broad review on merits ${ }^{201}$ and suggested that an award may be vacated under section 10(a)(4) of the FAA on the ground that arbitrators exceeded their powers, if the judges think that the tribunal's decision is wrong on merits. Despite coming to the same conclusion as the District Court, which found that the award was in manifest disregard of the law, ${ }^{202}$ the Supreme Court stated that it

“do[es] not decide whether 'manifest disregard' survives [their] decision in Hall Street Associates $[\ldots]$ as an independent ground for review or as a judicial gloss on the enumerated grounds for vacatur $[\ldots]]^{\prime 203}$

Nonetheless, the Supreme Court's decision implies that commercial arbitration awards are now subject to a rather liberal standard of review originally established in labor arbitrations. $^{204}$

\section{Conclusion}

The U.S. Supreme Court in Hall Street, although excluding the possibility of expanded judicial review under the FAA, failed to address whether the ground for vacatur "where the arbitrators exceeded their powers" could establish a review on merits. Thus, parties could well attempt to obtain the desired review on merits by stipulating that arbitrators exceed

198 See U.S. Supreme Court of 14/5/2001, No. 00-1210, Major League Baseball Players Association v. Garvey, 532 U.S. 504, p. 509, in accord with U.S. Supreme Court of 20/6/1960, No. 538, United Steelworkers of America v. Enterprise Wheel \& Car Corp., 363 U.S. 593, p. 597. See also Moses, (fn. 194); Goodrich, Dispensing Injustice: Stolt-Nielsen and its Implications, J. Disp. Resol. 2011,pp. 202 and 204.

199 U.S. Supreme Court of 27/4/2010, No. 08-1198, Stolt-Nielsen S.A. v. Animalfeeds International Corp., 559 U.S. 662, p. 664 (citing U.S. Supreme Court of 6/3/1989, No. 87-1318, Volt Information Sciences, Inc. v. Board of Trustees of Leland Stanford Junior University, 489 U.S. 468, p. 479).

200 U.S. Supreme Court of 27/4/2010, No. 08-1198, Stolt-Nielsen S.A. v. Animalfeeds International Corp., 559 U.S. 662, p. 672.

201 The Supreme Court applied a more rigid test then the one permitted by the manifest disregard of the law - the court conducted a de novo review. See Dissent of Justice Ginsburg in U.S. Supreme Court of 27/4/2010, No. 08-1198, Stolt-Nielsen S.A. v. Animalfeeds International Corp., 559 U.S. 662, p. 688: "The Court [...] indulging in de novo review, overturns the ruling of experienced arbitrators". See also Davis, The End of an Error: Replacing Manifest Disregard with a New Framework for Reviewing Arbitration Awards, Clev. St. L. Rev. 60 (2012), p. 122.

202 See ibid., p. 91.

203 U.S. Supreme Court of 27/4/2010, No. 08-1198, Stolt-Nielsen S.A. et al. v. Animalfeeds International Corp., 559 U.S. 662, p. 672, fn. 3.

204 See Loree Jr., Stolt-Nielsen Delivers a new FAA Rule - and then Federalizes the Law of Contracts, Alternatives to High Cost Litig. 28 (2010), p. 129. 
their powers if they err in their findings. ${ }^{205}$ This would have the same effect as a provision expanding judicial review, but instead of constituting an additional ground to those contained in section 10 of the FAA, it relies on a ground already set out in the FAA. ${ }^{206}$ The difference is only in the subject at which it is directed. In the first case, the provision is directed at the arbitrators personally and prohibits them from committing errors, while in the second case the provision is directed at judges, ordering them to conduct a specific standard of review.

Multiple courts and commentators support the position that parties may expand judicial review by means of section 10(a)(4) of the FAA. ${ }^{207}$ As one commentator pointed out, allowing parties to do so would represent

"a return to a well-accepted means of contracting for expanded review". ${ }^{208}$

Others, however, consider it invalid and only a way to indirectly get what the Supreme Court in Hall Street explicitly disallowed. ${ }^{209}$

Yet the U.S. Supreme Court seemed to recognize this possibility in Stolt-Nielsen, where it conducted a de facto review on merits and vacated it under section 10(a)(4) of the FAA on the ground that "the arbitrators exceeded their powers". Admittedly, in Stolt-Nielsen there was no agreement limiting arbitrators' power to commit errors, the court instead dealing with a situation where the tribunal allegedly imposed its own view of public policy and in that way exceeded its powers. Nonetheless, the Supreme Court in Stolt-Nielsen conducted a review on the merits of the award on grounds that the "arbitrators exceeded their powers", thereby allowing for a fairly broad standard of judicial scrutiny in commercial arbitration. Consequently, the number of reviews on merits will probably increase in the future ${ }^{210}$ and this decision could be seen by federal courts as authorization for parties

205 Ellis, Imperfect Minimalism: Unanswered Questions in Hall Street Associates, L.L.C. v. Mattel, Inc., 128 S.Ct.1396 (2008), Harv. J.L.\& Pub. Pol'y 32 (2009), p. 1195 et seq.

206 See Drahozal, (fn. 152), p. 912.

207 See e.g., Supreme Court of California of 25/8/2008, No. S147767, Cable Connection, Inc. v. Directv, Inc., 44 Cal. 4th 1334; Supreme Court of Texas of 13/5/2011, No. 08-0613, Nafta Traders Inc. v. A. Quinn, 339 S.W.3d 84. See also Drahozal, (fn. 152), p. 916; Ellis, (fn. 205), p. 1195 et seq.: "[...] this section 10 loophole complies with the text of Hall Street and the FAA while upholding the congressional intent of the statute." Rau, (fn. 160), p. 485 et seq.; Cole, (fn. 41), p. 225; Ware, in: Chernick/Rylaarsdam/Stipanowich et al., The Future of Commercial Arbitration, Pepp. Disp. Resol. L.J. 9 (2009), p. 421.

208 See Drahozal, (fn. 152), p. 916. In support of his position, Drahozal is citing several leading academic commentators who are of the same position.

209 See Reuben, Personal Autonomy and Vacatur After Hall Street, Penn St. L. Rev. 113 (2009), p. 1135: "[...] parties should not be able to accomplish indirectly what Hall Street prohibits them from accomplishing directly. The fundamental principle behind Hall Street is a rule of judicial non-intervention [...]". Stipanowich, Revelation and Reaction: The Struggle to Shape American Arbitration, 2014, p. 15, fn. 75; Davis, (fn. 200), p. 99 et seq., fn. 88. See also U.S. District Court, S.D. Texas of 27/6/2008, Civil Action No. H-06-2198, Wood v. PennTex Resources LP, 2008 WL 2609319 (S.D.Tex.), p. 8: "[...] would result in precisely the "full-bore legal and evidentiary appeals' that the Court held the FAA precluded. [...] This reading would impermissibly circumvent Hall Street."

210 See Loree Jr., (fn. 204), p. 129. 
to expand the scope of judicial review by relying on the same section 10(a)(4) of the FAA. As pointed out by one commentator,

"[r]ather than evading Hall Street, reliance on section 10(a)(4) of the FAA as a basis for vacating awards is conforming to Hall Street - the parties are seeking vacatur only on grounds set out in the FAA". ${ }^{211}$

Given, however, the strong resistance to expanded judicial review in the aftermath of Hall Street, ${ }^{212}$ parties surely take a big risk by agreeing on a review of merits based on the ground that arbitrators exceeded their power. Ultimately, the validity of contractual expansion of judicial review on that ground under the FAA will remain precarious until the Supreme Court decides the question explicitly, thereby bringing the question to an end.

\section{F. Possible solutions for parties seeking a review on merits}

As previously discussed, the majority of national arbitration laws provide for limited grounds for annulment of arbitral awards, which are generally restricted to major procedural deficiencies and public policy considerations. ${ }^{213}$ Furthermore, courts are reluctant to validate parties' agreements expanding judicial review beyond what is provided for in the law.

Until these changes, parties are advised to carefully negotiate and draft their arbitration agreements. In order to obtain the desired review on merits by courts, parties have two possibilities: either to seat their arbitration in a state which explicitly allows parties to expand judicial review by contract or to seat their arbitration in a state which provides more extensive grounds for annulment than the currently accepted standard.

Another possibility to obtain the desired review on merits, albeit not through the courts, would be to agree on an internal arbitral appeal, whereby a second instance of the tribunal would conduct the review on merits.

\section{Jurisdictions explicitly allowing expanded judicial review}

Unfortunately, only a few states explicitly allow parties to arbitration to contractually agree on a wider standard of review than that provided by the default rule. Swiss law, although not expressly providing for the validity of parties' agreement expanding judicial review, creates a backdoor for parties in international arbitration, who want a higher standard of review than the one provided by Article 190 of the Private International Law Act 1987. ${ }^{214}$ Parties are granted the possibility of explicitly excluding the application of chap-

211 Drahozal, (fn. 152), p. 916.

212 See Supreme Court of Tennessee of 22/9/2010, No. W2008-01366-SC-611-CV, Pugh's Lawn Landscape Company Inc. v. Jaycon Development Corporation, p. 9; Supreme Court of Georgia of 28/6/2010, No. S09G2081, Brookfield Country Club Inc. v. St. James-Brookfield LLC, 287 Ga. 408, p. 413; Supreme Judicial Court of Maine of 20/3/2011, BCD-10-256, HL 1 LLC v. Riverwalk $L L C, 15$ A.3d 725, p. 736. See also Smit, Hall Street Associates v. Mattel: A Critical Comment, Am. Rev. Int'l Arb. 17 (2006), p. 513.

213 See B.IV.

214 Article 190 of the PILA provides for annulment in cases of important procedural deficiencies and public policy violation, which reflects the currently accepted standard of review. 
ter 12 referring to international arbitration and to agree on the application of the third part of the Civil Procedure Code for domestic arbitration. ${ }^{215}$ According to Article 393, an award may be contested if

"the award is arbitrary in its result because it is based on findings that are obviously contrary to the facts as stated in the case files or because it constitutes an obvious violation of law or equity". ${ }^{216}$

The new Hong Kong Arbitration Ordinance, which came into force in 2011 and is based largely on the Model Law, provides for "opt-in" provisions that parties may incorporate in their arbitration agreement should they wish to do so. ${ }^{217}$ One such "opt-in" provision is section 5 of Schedule 2, which provides for an appeal against arbitral awards on questions of law. ${ }^{218}$

Furthermore, parties are expressly granted the possibility of contractually agreeing on a higher standard of review by the Israeli Arbitration Law $1968^{219}$ and by the New Jersey Statute. ${ }^{220}$

Apart from choosing these states as the venue of arbitration, parties could further opt for states allowing for an expanded judicial review via its jurisprudence. In addition to the states already elaborated on, namely California, ${ }^{221}$ Texas $^{222}$ and Germany, ${ }^{223}$ parties are also free to expand judicial review under the arbitration law of Connecticut ${ }^{224}$ and Alaba-

215 See Article 176(2) of the PILA. See also Orelli, Chapter 2, Part II: Commentary on Chapter 12 PILS, Article 176 [Field of application; seat of the arbitral tribunal], in: Arroyo (ed.), Arbitration in Switzerland: The Practitioner's Guide, 2013, p. 2.

216 See Article 393(e) of the Civil Procedure Code.

217 See section 99 of the Hong Kong Arbitration Ordinance 2014 (headed "Arbitration agreements may provide expressly for opt-in provisions").

218 See section 5 of Schedule 2 in connection with section 81(2)(c) of the Hong Kong Arbitration Ordinance.

219 Article 29B(a) of the Israeli Arbitration Law states: "Parties to an arbitration agreement, who have stipulated that the arbitrator shall decide in accordance with the substantial law, may agree that the Award is appealable, in the court's leave; whereas a fundamental mistake has occurred in the implementation of law which could cause a miscarriage of justice $[\ldots]$ ".

220 Article 2A:23B-4(c) of the New Jersey Statute authorizes expanded judicial review, stating that "nothing in this act shall preclude the parties from expanding the scope of judicial review of an award by expressly providing for such expansion in a record." See Stipanowich, Arbitration and Choice: Taking Charge of the "New Litigation" (Symposium Keynote Presentation), DePaul Bus. \& Comm. L.J. 7 (2009), p. 427 et seq., fn. 219; Huber, State Regulation of Arbitration proceedings: Judicial Review of Arbitration Awards by State Courts, Cardozo J. Conflict Resol. 10 (2009), p. 541 et seq.

221 Supreme Court of California of 25/8/2008, No. S147767, Cable Connection, Inc. v. Directv, Inc., 44 Cal. 4th 1334. See E.IV.

222 Supreme Court of Texas of 13/5/2011, No. 08-0613, Nafta Traders Inc. v. A. Quinn, 339 S.W. 3d 84. See E.IV.

223 German Supreme Court of 1/3/2007, III ZB 7/06. See D.II.2.

224 Superior Court of Connecticut of 2/8/2010, No. X08CV044002173S, East Greyrock LLC v. OBC Associates Inc., 2010 WL 3448075 (Conn.Super.), p. 4, fn. 9. Accord, although in dictum, Supreme Court of Connecticut of 3/6/2008, No. 18055, HH East Parcel LLC v. Handy and Harman Inc., 287 Conn. 189, p. 204, fn. 16. 
ma. ${ }^{225}$ It is important to note that parties planning to subject their arbitration to a U.S. state's law have to include a particular reference to the arbitration law of that state; a mere reference to a state's substantive law in general is insufficient, as in this case the federal law will apply. ${ }^{226}$

\section{Jurisdictions providing more extensive grounds for annulment}

Despite the tendency to limit court involvement, some states provide in their arbitration law annulment grounds that are more extensive than the usually accepted standard under the UNCITRAL Model Law. Thus, parties could choose to subject their arbitration to the arbitration law of these states in order to obtain a review on merits.

Probably the most prominent example is England, where section 69 of the English Arbitration Act 1996 provides for appeals on points of law. This is restricted to questions of English law ${ }^{227}$ and excludes questions of fact. ${ }^{228}$ The possibility of an appeal, however, is subject to various limitations. Firstly, an appeal is possible unless there was an agreement to the contrary. ${ }^{229}$ But even if parties do not exclude it, an appeal can be commenced only if all the parties agreed thereto or, in the absence of such an agreement, with the leave of the court. ${ }^{230}$ Moreover, an appeal will only be granted if the court is satisfied that the tribunal's decision is obviously wrong or the question is of general public importance and if it finds that it is just and proper to decide the raised question. ${ }^{231}$

A limited right of review on points of law is also granted in New Zealand. ${ }^{232}$ Here an appeal can be initiated only if the parties agreed on it beforehand or after the award was rendered or, in absence of such an agreement, with the leave of the court. ${ }^{233}$ The court can, however, grant leave only if it feels that the determination of the question raised could substantially affect the rights of one or more of the parties, taking into account all the circumstances. ${ }^{234}$ The possibility to appeal on any questions of law is further granted in British Columbia by virtue of Article 31 of its Arbitration Act.

225 Supreme Court of Alabama of 18/6/2010, 1081688, Raymond James Financial Services Inc. v. Honea, 55 So.3d 1161, p. 1170.

226 See Mitzner, (fn. 152), pp. 191-195. For more detailed information see Burns, Freedom, Finality, and Federal Preemption: Seeking Expanded Judicial Review of Arbitration Awards under State Law after Hall Street, Fordham L. Rev. 78 (2010), p. 1813 et seqq.

227 See section 82(1) of the English Arbitration Act 1996. See Wolfson/Charlwood, Chapter 25: Challenges to Arbitration Awards, in: Lew/Bor/Fullelove et al. (eds.), Arbitration in England, with chapters on Scotland and Ireland, 2013, p. 545; Born, (fn. 1), p. 3349, fn. 1040.

228 See Queen's Bench Division (Commercial Court) of 5/11/2010, Guangzhou Dockyards Co. Ltd. v. E.N.E. Aegiali I, [2010] 2 C.L.C. 870, p. 878, para. 17: "The words cannot be construed as expanding the jurisdiction of the court to include an appeal to the court on a question of fact on the basis that the parties have agreed to such an appeal [...]".

229 See section 69(1) of the English Arbitration Act 1996. Parties can exclude an appeal expressly in the arbitration agreement or impliedly through the choice of institutional rules limiting the right to appeal. See Wolfson/Charlwood, (fn. 227), p. 543 et seq.; Born, (fn. 1), p. 3349.

230 See section 69(2) of the English Arbitration Act 1996.

231 See section 69(3) of the English Arbitration Act 1996. See also Born, (fn. 1), p. 3349 et seq.

232 See section 5 of Schedule 2 of New Zealand Arbitration Act 1996.

233 See section 5(1) of Schedule 2 of New Zealand Arbitration Act 1996.

234 See section 5(2) of Schedule 2 of New Zealand Arbitration Act 1996. 
Another option for parties seeking a review on merits would be to agree on arbitration in Ontario. Article 45 of the Ontario Arbitration Act 1991 allows parties to appeal on points of law, facts or a mixture of fact and law, if the parties agreed thereto. In the recent case of Zurich Insurance Co. v. Chubb Insurance Co. ${ }^{235}$ the highest court in Ontario decided which standard would be applicable in the event of an appeal. In case of an appeal on question of law the standard is correctness, while in case of questions of fact the standard is one of an overriding a palpable error. Last, when deciding on questions of mixed fact and law, the standard is reasonableness. ${ }^{236}$

Furthermore, wide judicial review of awards is provided in Libya. The Libyan arbitration law recognizes several means of recourse against an arbitral award: setting aside, an appeal and revision. ${ }^{237}$ The appeal procedure is regulated in Article 767 of the Code of Civil and Commercial Procedure $1953,{ }^{238}$ according to which an appeal has to be made in accordance with rules applicable to an appeal against a court judgment, with the appeal being permitted subject to four restrictions. ${ }^{239}$ At this point, it is noteworthy that a new draft of the arbitration law was issued in Libya in 2009 but has not yet been promulgated. ${ }^{240}$ Nonetheless, Article 43 of the new Draft Law on arbitration retains the right to appeal, albeit with fewer restrictions. ${ }^{241}$ Under the new draft, an appeal is available only if the parties explicitly agreed thereto, whereas under the current law it is available so long as the parties did not waive this right. Further, arbitral awards are appealable even if the arbitrators acted as "amiables compositeurs", impossible under the current law. ${ }^{242}$

An appeal on merits is also possible under the arbitration law in Argentina. ${ }^{243}$ So too in Sweden if parties agree thereto, despite not being expressly stated in the arbitration law. ${ }^{244}$

235 Ontario Court of Appeals of 15/5/2014, CA C57553, Zurich Insurance Co. v. Chubb Insurance Co., 2014 ONCA 400.

236 Ibid., para. 13 (citing Ontario Superior Court of Justice of 25/8/2008, 08-CV-346482 PD3, 08CV-353594 PD2, Aviva Insurance Co. of Canada v. Royal \& SunAlliance Insurance Co., 66 C.C.L.I (4th) 262, para. 7).

237 See El Ahdab/El Ahdab, Arbitration in Libya, in: El Ahdab/El Ahdab, Arbitration with the Arab Countries, 2011, pp. 479-482.

238 The text of the provision can be found in Libya/Annex I Code of Civil and Commercial Procedure 1953, in: Paulsson (ed.), International Handbook on Commercial Arbitration, 1984, www.kluwerarbitration.com $(1 / 10 / 2014)$.

239 See Article 767 of the Code of Civil and Commercial Procedure 1953. See also El Ahdab/El Ahdab, (fn. 237), p. 479.

240 See ibid., p. 457.

241 See El Ahdab/El Ahdab, New Draft Law on Arbitration, in: El Ahdab/El Ahdab, (fn. 237), pp. 1002-1018. See also Abouda, The New Libyan Draft Law on Arbitration, International Journal of Arab Arbitration 2 (2010), p. 38.

242 Compare Article 767 of the Libya Code of Civil and Commercial Procedure 1953 with Article 43 of the New Draft Law on Arbitration.

243 See Article 758 of the Argentina National Code of Civil and Commercial Procedure, to be found in Argentina/Annex I National Code of Civil and Commercial Procedure, in: Paulsson, (fn. 238). See also Tawil, National Report for Argentina (2011), in: Paulsson, (fn. 238), p. 36.

244 See Franke, National Report for Sweden (2011), in: Paulsson, (fn. 238), p. 23. See also Oldenstam/von Pachelbel, Sweden, in: Weigand, (fn. 62), p. 803, para. 11.253. 
As can be seen, a considerable number of arbitration laws provide for more extensive grounds of judicial review compared to the usually accepted standard. Still, this is not an exhaustive list and the number of such countries is probably higher. ${ }^{245}$

\section{Appeal to a tribunal of second-instance}

Parties seeking a review on merits could also possibly obtain it by means of an arbitral appeal to a tribunal of second instance. Such an appeal is a common feature in commodity trade and in that respect, by way of example the arbitration rules of the Grain and Feed Trade Association (GAFTA), provide a possibility to appeal against an award to a board of appeal which will hear the case anew. ${ }^{246}$

The fact that an arbitral appeal is rarely used in commercial arbitration ${ }^{247}$ does not exclude the possibility of such an appeal. On the contrary, such an appeal is available under most arbitration laws. ${ }^{248}$ As one can see from the Explanatory Note on the UNCITRAL Model Law, the Model Law does not preclude parties from appealing to a tribunal of second instance. ${ }^{249}$ The majority of national arbitration laws, like the Model Law, do not provide for a review on merits by a second arbitral panel. Nonetheless, such an arbitral appeal is not deemed excluded under their law. ${ }^{250}$ Moreover, some states expressly allow parties to have an arbitral appeal, such as Argentina ${ }^{251}$ or the Netherlands. ${ }^{252}$

Parties who have provided for an arbitral appeal in their arbitration agreement can construe the arbitral appeal according to their needs. As a result, parties can appoint a completely new panel to review the merits. If the parties desire a review by state court judges in the belief that they will conduct the review more accurately, the parties are free to appoint judges to perform the review. Generally, parties will be advised to appoint retired judges because most state laws prohibit active judges from acting as arbitrators. ${ }^{253}$ In Germany, however, active judges can be arbitrators so long as they are appointed by the mutual con-

245 See Gharavi, (fn. 9), pp. 36-40.

246 See rule 10.1 and 12.4 of the GAFTA No. 125 Arbitration Rules, www.scribd.com/doc/ 35608972/Grain-and-Feed-Trade-Association-125-Arbitration-Rules (1/10/2014). An arbitral appeal is provided also by sections 28-33 of the Arbitration Rules of the German Waren-Verein der Hamburger Börse e.V., www.waren-verein.de/en/permanent-court-of-arbitration/conditions-of-business (1/10/2014).

247 See Lew/Mistelis/Kröll, (fn. 3), p. 663.

248 Contrary e.g., Italy where no appeal to a second-instance tribunal is allowed. See Rubino-Sammartan, Italy, in: Weigand, (fn. 62), p. 596, para. 8.225.

249 UNCITRAL Secretariat, (fn. 9), para. 45.

250 This is true e.g., for China, Hong Kong, Singapore, Peru, Unites States, Switzerland, England, Germany, Austria. For more information see relevant parts in Weigand, (fn. 62), as well as Paulsson, (fn. 238).

251 See Article 763 of the National Code of Civil and Commercial Procedure. For the text of provision or further information consult the authorities from fn. 243.

252 See Article 1061a of the Code of Civil Procedure 2014. The new arbitration law devotes the whole section $3 \mathrm{~A}$ to the arbitral appeal.

253 See e.g., Canon 4(A)(4) of the Code of Conduct for United States Judges; section 4F of the Code of Judicial Conduct of the American Bar association; section 9.1 of the Guide to Judicial Conduct, Judiciary of England and Wales, March 2013. 
sent of both parties or by an independent body. ${ }^{254}$ Should parties want an institutional arbitral appeal, they could choose arbitration rules allowing for such an appeal, for example the JAMS ${ }^{255}$ Arbitration Rules, which allow parties to agree on an Optional Arbitration Appeals Procedure ${ }^{256}$ or the Arbitration Rules of the European Court of Arbitration, which prescribe an appeal to an Appellate Arbitral Tribunal unless it is excluded by the parties or runs counter to provisions of the applicable mandatory law. ${ }^{257}$ A further possibility for parties arbitrating their disputes in the United States is to make use of the Arbitration Appeal Procedure provided by the International Institute for Conflict Prevention \& Resolution (CPR). ${ }^{258}$

Agreeing on a review on merits to be conducted by a tribunal of second instance is the less risky option for parties due to the general acceptance of such a review by national laws, the high degree of self-control by parties and the preservation of advantages such as confidentiality of the process, which would be compromised in cases of a judicial review on merits.

\section{G. Should parties be allowed to expand judicial review?}

When arbitration was "born", courts took a rather hostile approach towards it and at that time limitations of court involvement in arbitration were welcomed as a clear pro-arbitration measure, protecting parties from unwanted court interference. Yet as Várady rightly declared, it seems that the brave fighters for arbitration did not notice that the war is over and that arbitration had won. ${ }^{259}$ These days arbitration is accepted as the predominant method of resolving international commercial disputes, with courts assisting rather than disturbing arbitration.

The great success of arbitration as an alternative to court proceedings can be attributed to a number of grounds, but most important is the right and freedom of informed parties to tailor the procedure for the dispute resolution to their needs. Historically, by choosing arbitration commercial parties opted to replace the multi-step process of court litigation with being bound by a final award granted by arbitrators. Advocates of arbitration were eager to fulfil the parties' expectations and drew on the finality of awards as a mantra. However, relatively recently commercial parties have started to express some scepticism towards arbitration and in numerous cases have agreed to expand judicial review.

254 See section 40 Deutsches Richtergesetz.

255 JAMS is the largest private alternative dispute resolution (ADR) provider in the world. For more information visit www.jamsadr.com (1/10/2014).

256 The text of JAMS Optional Arbitration Appeals Procedure is available at www.jamsadr.com/ appeal/ (1/10/2014).

257 Article 28 of the Arbitration Rules of the European Court of Arbitration. See also Rubino-Sammartano, International Arbitration Law and Practice, 3rd ed. 2014, p. 1344 et seq.

258 Rules of Appeal Procedures are available at www.cpradr.org/RulesCaseServices/Arbitration/ AppellateArbitrationProcedure/Rules.aspx (1/10/2014).

259 See Várady, On the Option of a Contractual Extension of Judicial Review of Arbitral Awards or: What is Actually Pro-Arbitration?, Zbornik PFZ 56 (2006), p. 456. 
Many have highlighted the element of finality of award and hence aim to disallow parties to expand judicial review. ${ }^{260}$ But such an approach is unreasonably rigid. Arbitration poses an alternative form of dispute resolution, allowing commercial parties to contractually determine how their dispute is resolved. A need for court scrutiny of awards undeniably exists, the best example therefor being Belgium's failed project of mandatory exclusion of court review. In 1985 Belgium completely prohibited recourse against awards in disputes between foreigners, hoping thereby to attract business people. However, the business community felt anxious about such a system and in 1998 the country decided to enact a new statute providing for judicial scrutiny. ${ }^{261}$ Still, every standard of judicial review, be it a limited or a broad one, represents a trade-off between the advantages of arbitration. Broad scrutiny by courts will sacrifice the speed and finality of arbitration, while limited recourse will sacrifice its predictability and possibly the quality of decisions. ${ }^{262}$ Finality is one of the many advantages of arbitration that attracts business entities but it is not the heart of it. What brings arbitration to life is parties' agreement. Hence, which bargain proves the better one is uncertain and depends mostly on parties' needs.

The same reasoning is to be applied regarding the trade-off between other advantages of arbitration, for instance the ancillary advantage of confidentiality that would be compromised with a review on merits by state courts. Confidentiality plays an inferior role in arbitration and often it is not even stated when listing the advantages of arbitration. ${ }^{263}$ More importantly, however, no duty of confidentiality exists in arbitration and parties are free to choose between confidential or non-confidential arbitration. ${ }^{264}$

Moreover, prohibiting parties from expanding judicial review would run counter to the purpose of limiting review by state courts, namely that of protecting the parties from unwanted court intervention. Legislators, in order to protect parties' agreement and expectations, enacted detailed arbitration laws that are now construed exactly against parties' expectations. This author frankly refuses to believe that such an approach is in the spirit of arbitration.

In addition, excluding a review on merits could have counterproductive effect on arbitration. Parties who want to combine the advantages of arbitration with a court review on merits would be left with no other possibility than to commence litigation in state courts. Furthermore, a complete exclusion of review on merits by state courts could lead to a situation where arbitrators, feeling comfortable in their role of the untouchable decision-

260 See e.g., Smit, Contractual Modification of the Scope of Review of Arbitral Awards, Am. Rev. Int'1 Arb. 8 (1997), p. 147 et seqq.; Reuben, Process Purity and Innovation in Dispute Resolution: A Response to Professors Stempel, Cole, and Drahozal, Nev. L. J. 8 (2007), p. 271 et seqq.; Wolff, (fn. 38), p. 626.

261 See Park, Why Courts Review Arbitral Awards, in: Briner/Fortier/Berger at al. (eds.), Recht der Internationalen Wirtschaft und Streiterledigung im 21. Jahrhundert: Liber Amicorum KarlHeinz Böckstiegel, 2001, p. 599 et seq. See also Gharavi, (fn. 9), pp. 25-27.

262 See Ginsburg, (fn. 160), p. 1014.

263 See Born, (fn. 1), pp. 3-5, Lew/Mistelis/Kröll, (fn. 3), pp. 2-4; Lowenfeld, Introduction: Why Arbitrate?, in: Kolkey/Chernick/Reeves Neal (eds.), Practitioner's Handbook on International Arbitration and Mediation, 3rd ed. 2012, p. 3 et seq.

264 See Born, Planning for International Dispute Resolution, J. Int'l Arb. 17 (2000), p. 69; Born, (fn. 1), p. 2784 et seq. 
maker, would have no incentive to render high-quality decisions in accordance with law and fact. This would undermine the quality of arbitration and parties' confidence in the arbitral process, which would lead parties to refrain from arbitration in the future and instead opt for court litigation. Thus, granting parties the possibility to contract for a review on merits could motivate arbitrators to render well-reasoned decisions so as to prevent their award being annulled, thereby enhancing parties' trust in arbitration.

Moreover, a review on merits cannot be considered contrary to the institution of arbitration and national arbitration laws allowing such a review support this. The best example is England, whose Arbitration Act 1996 allows a review on merits but nevertheless is considered an attractive arbitration venue for commercial parties.

For these reasons, parties should be granted the right to expand judicial review. Parties' possibility to expand judicial review would have no negative implications on arbitration itself, as parties preferring limited recourse against an award would be bound by the existing default rules, while parties preferring a review of merits would be granted such a possibility when the parties expressly stipulated it in their arbitration agreement. Admittedly, this right should not be unrestricted. As Judge Kozinski stated in his concurring opinion in LaPine Technology Corp. v. Kyocera Corp. in relation to granting parties the right to expand judicial review, the outcome would be different

"if the agreement provided that the district judge would review the award by flipping a coin or studying the entrails of a dead fowl". ${ }^{265}$

Parties should not be able to introduce a standard of review unknown by the competent court and in that way impose a higher burden on it. If the competent court were entitled to perform a specific standard of review when the case was brought to it by way of litigation, the court should not reject the performance of such a standard of review if expressly agreed upon between the parties to arbitration.

\section{H. Conclusion}

Agreeing on arbitration with a state court review on merits raises complex issues and lively discussions between its various proponents and opponents. The first thing an outsider would ask is: who is right? The answer is far from easy and it is doubtful whether it can be answered with certainty in cases where there is no express provision in the law allowing or prohibiting it. For this reason the best and worst answer would be: it depends!

Generally, national arbitration laws do not explicitly regulate the issue of contractually expanded judicial review and hence the courts seem to be in an unenviable position when confronted with the validity of such agreements. Although a considerable amount of literature and court rulings deal with this issue, they do not present a real guidance for the courts due to the existent split. The answer will hence depend mostly on courts' perception of arbitration: whether it is a process mainly characterized by party autonomy or finality of

265 U.S. Court of Appeals, Ninth Circuit of 9/12/1997, Nos. 96-15319, 96-15321, 96-16142, 96-16143, 96-16318, LaPine Technology Corporation v. Kyocera Corporation, 130 F.3d 884, p. 891. 
awards. Consequently, until the law explicitly regulates this matter, the problem will remain and parties eager to have a review on merits will be left with a large degree of legal uncertainty regarding the validity of their agreement.

Notwithstanding the lack of a clear solution, some circumstances cannot be denied and should be taken into account when discussing the option of expanded judicial review. Compared with the past, the commercial settings changed considerably over the last century. Remarkable trade liberalization at the international level led to significant growth in international business transactions. Consequently, the transactions grew in size and importance and, ergo, possible disputes may include not only astronomic amounts of money but also complex legal and factual issues. Small disputes will normally have merely a minor influence on the parties, who will prefer a quick resolution of their disputes by a final award in order to continue their business relationship. While the finality of award will play an important role for parties in small disputes, it is highly doubtful whether parties would be satisfied with a limited review in "bet-the-company" cases. In such cases, where the survival of the commercial entities is at stake, the parties may become more risk-averse and search for ways to protect them from clearly erroneous awards. The United States Supreme Court recognized the problem in AT\&T Mobility v. Vincent Conception ${ }^{266}$ where it stated that it is "hard to believe that defendants would bet the company with no effective means of review" and thus, due to the exclusion of possible review on merits, "[a]rbitration is poorly suited" to high-stake cases.

As the commercial settings changed, so should arbitration. Hence, what was once proarbitration is not necessarily pro-arbitration anymore. In order for arbitration to remain an attractive method of dispute resolution for commercial entities, particularly when highstake or bet-the-company cases are involved, a revision of the current legislation, which is woefully out of date, is needed.

The need for a revision of arbitration laws is testified by the numerous court rulings on the validity of expanded judicial review. Take the situation in the United States, where even after the ruling of the U.S. Supreme Court in Hall Street which prohibited vacatur on grounds other than the one set out in section 10FAA, parties continued to agree on expanded judicial review and several courts allowed for such possibility. Notwithstanding one's accord with these rulings, they are evidence of the need for a review on merits in the arbitral community.

Arbitration is a private dispute settlement method based on parties' agreement to submit their disputes to arbitration in the manner it serves their needs. True, finality of arbitral awards is a big advantage of arbitration compared to court proceedings, but finality remains just that - an advantage of arbitration. Hence, parties should be granted the possibility to trade this advantage off for the legal certainty achieved by a review of the award on merits. Construing the law so rigidly as to create a "one-size-fits-all" arbitration framework, no matter what parties' needs and wishes are, would be antagonistic to the nature of arbitration.

266 U.S. Supreme Court of 27/4/2011, No. 09-893, AT\&T Mobility LLC v. Vincent Conception, 131 S.Ct. 1740 , p. 1752, para. 12. Although dealing with class arbitration, the reasoning can be transposed to all high stake cases. 
In any case, the question of contractually expanded judicial review cannot be ignored and a clear answer should be given to parties wanting to opt into a review on merits. This would enable them to better estimate their possibilities and to pick the method of dispute resolution that serves their overall needs best. It is yet to be seen which direction will be taken by legislators and in which direction arbitration will go - whether arbitration will become a formalistic procedure ignoring the needs of the business community or serve these needs as it was initially intended to. 